\title{
Multi-product biorefineries from lignocelluloses: a pathway to revitalisation of the sugar industry?
}

\author{
Somayeh Farzad ${ }^{1 \dagger}$, Mohsen Ali Mandegari ${ }^{1 \dagger}$, Miao Guo ${ }^{2}$, Kathleen F. Haigh ${ }^{1}$, Nilay Shah ${ }^{2}$ \\ and Johann F. Görgens ${ }^{1 *}$
}

\begin{abstract}
Background: Driven by a range of sustainability challenges, e.g. climate change, resource depletion and expanding populations, a circular bioeconomy is emerging and expected to evolve progressively in the coming decades. South Africa along with other BRICS countries (Brazil, Russia, India and China) represents the emerging bioeconomy and contributes significantly to global sugar market. In our research, South Africa is used as a case study to demonstrate the sustainable design for the future biorefineries annexed to existing sugar industry. Detailed techno-economic evaluation and Life Cycle Assessment (LCA) were applied to model alternative routes for converting sugarcane residues (bagasse and trash) to selected biofuel and/or biochemicals (ethanol, ethanol and lactic acid, ethanol and furfural, butanol, methanol and Fischer-Tropsch synthesis, with co-production of surplus electricity) in an energy self-sufficient biorefinery system.
\end{abstract}

Results: Economic assessment indicated that methanol synthesis with an internal rate of return (IRR) of $16.7 \%$ and ethanol-lactic acid co-production (20.5\%) met the minimum investment criteria of 15\%, while the latter had the lowest sensitivity to market price amongst all the scenarios. LCA results demonstrated that sugarcane cultivation was the most significant contributor to environmental impacts in all of the scenarios, other than the furfural production scenario in which a key step, a biphasic process with tetrahydrofuran solvent, had the most significant contribution.

Conclusion: Overall, the thermochemical routes presented environmental advantages over biochemical pathways on most of the impact categories, except for acidification and eutrophication. Of the investigated scenarios, furfural production delivered the inferior environmental performance, while methanol production performed best due to its low reagent consumption. The combined techno-economic and environmental assessments identified the performance-limiting steps in the $2 \mathrm{G}$ biorefinery design for sugarcane industry and highlighted the technology development opportunities under circular bioeconomy context.

Keywords: Biorefinery, Biofuel, Biochemical, Techno-economic evaluation, Life cycle assessment (LCA), Sugarcane residues, Multi-products

\section{Background}

A range of environmental concerns, e.g. fossil fuel depletion and climate change, have triggered development

\footnotetext{
*Correspondence: jgorgens@sun.ac.za

'Somayeh Farzad and Mohsen Ali Mandegari contributed equally to this work

${ }^{1}$ Department of Process Engineering, Stellenbosch University, Stellenbosch 7600, South Africa

Full list of author information is available at the end of the article
}

of the bio-based economy, where biorefineries and bioproducts are key features [1]. Various government initiatives have been launched at international, national and regional levels to support the biofuel, bioenergy and other biochemical production, such as mandated biofuel blending targets in the United States (USA), Brazil, Canada and several EU member states [2-6]. The biofuels strategy in South Africa (SA) targets at a $2 \%$ penetration of liquid biofuels in the national fuel market, aiming 
to boost the rural economy and create "green" jobs [7]. To date, investments in biofuels in South Africa have been very modest. However, conversion of $70 \%$ of the total estimated biomass availability would be sufficient to meet $24 \%$ of the SA liquid fuel needs as bioethanol equivalent [7]. Besides, bio-based chemicals including non-food starch, cellulose fibres and cellulose derivatives, tall oils, fatty acids and fermentation products have been also regarded as important components of the bio-based economy [8-10].

Amongst a range of potential bio-based resources, lignocellulosic biomasses (the so-called second-generation or $2 \mathrm{G}$ biomass) especially waste $2 \mathrm{G}$ feedstocks including agroprocessing residues (e.g. sugarcane bagasse) are promising resources for production of bio-based fuels and chemicals, due to their relative abundance, potential lower supply costs and avoidance of land use competition with food crops $[11,12]$. Considerable potential $2 \mathrm{G}$ waste biomass is generated annually in SA (26 million tonnes per annum including agricultural and forestry residues and invasive plants), and provides a significant opportunity for the SA biofuels/biochemical industry as well as potential for rural economy development [13]. Such 2G waste resources and related economic sectors can play a significant role in a potential circular bioeconomy, contributing to a resource-efficient sustainable SA future.

South Africa along with other BRICS countries (Brazil, Russia, India and China) represents the emerging market and growing world economy in the coming decades. BRICS countries dominate the global sugar market [14]. SA has the largest sugar industry in African continent, making substantial contribution to the development of national economy [15]. However, the global sugar industry generally is facing a range of issues such as the fluctuating and low global sugar prices, increasing competition with low-cost global sugar producers, increasing energy and agricultural input costs and ageing facilities [16]. More efficient use of $2 \mathrm{G}$ sugarcane residues to broaden the product range of sugar mills has been proposed as a potential solution [13]. Citing SA as an example, about 270-280 kg bagasse are generated per tonne of harvested cane, which is primarily used inefficiently as boiler fuel in current sugar mills [17]. Approximately 7.6 million tonnes of bagasse is generated in South Africa annually [18], which potentially could lead to a $\$ 1.5$ billion bioethanol market [19].

Biorefineries are regarded as the cornerstone of a bioeconomy, where a range of thermochemical and biochemical routes including non-catalytic or catalytic technologies can be deployed and integrated to transform biomass organic molecules to a plethora of bio-products [20]. In the context of sugar industry, a biorefinery could be annexed to a sugar mill to increase diversification and support regional and rural development. A number of economic assessments have been published on biofuel production from $2 \mathrm{G}$ waste biomass, considering biochemical $[21,22]$ or thermochemical technologies [23-26]. Production of value-added chemicals and polymers from lignocellulosic waste biomass has been also explored in the past few years [10, 27-29]. Research and development continue to be necessary on economic and environmental aspects of co-producing biochemicals along with biofuel.

Apart from economic viability, environmental impact is another important factor underpinning sustainable development of biorefinery systems. A widely recognised environmental impact assessment tool is life cycle assessment (LCA) [30], which is a cradle-to-grave evaluation approach formalised by the International Organization for Standardization [31]. LCA has been widely applied in biorefinery technologies [32-34], but the majority of the studies focused on GHG emissions and energy balances with less attention paid to the wider range of environmental impact categories [35]. Apart from environmental and economic aspects, biorefinery can contribute to poverty reduction in rural areas through job creation and increased income for small farmers [36].

A review of literature suggests that very limited research has been conducted on the combined LCA and economic assessments, to compare alternative technological approaches to biofuel and biochemical production from lignocellulosic waste biomass. The overall objective of this work is to assess the holistic impacts of diversification in the sugarcane industry through the development of lignocellulosic biorefineries, in terms of economic viability, environmental and social benefits of using $2 \mathrm{G}$ waste resource as feedstock. In this regard, six potential biochemical/thermochemical pathways-bioethanol, bioethanol and lactic acid, bioethanol and furfural, butanol, methanol and Fischer-Tropsch synthesis-have been investigated (see Table 2 for the justification of these choices) to explore sustainable biorefinery design. South Africa sugarcane system is used as a representative case study in our modelling research to identify the performance-limiting steps in the biorefinery design and highlight the future technology development opportunities. Overall, this study aims to provide scientific insights into the biorefinery 'plug-in' (annexed) solutions to existing sugar industry that could contribute best to the sustainability and circular bioeconomy development under the BRICS emerging economy context.

\section{Methods}

\section{Sugarcane $2 \mathrm{G}$ biomass availability}

The 2G sugarcane residues, which could be utilised as biorefinery biomass, include bagasse (currently 
inefficiently burned at sugar mills) and brown leaves (currently burned in the fields) $[18,37]$. As demonstrated in Table 1 , the biomass availability [ 65 tonnes dry mass per hour $(\mathrm{tDM} / \mathrm{h})]$ has been calculated based on the average data in South Africa. It is assumed that only the brown leaf component of sugarcane harvesting residues will be made available by a green-cane-harvesting approach, while the tops (green leaves) will be left in the field to maintain soil fertility $[18,38]$. Such harvesting approach represents South Africa cane trash recovery system, which has been discussed in details in previous studies [18].

In this study, the average chemical composition of bagasse and brown leaves of SA sugar mills has been used, i.e. $40.7 \%$ cellulose, $27.1 \%$ hemicellulose, $21.9 \%$ lignin, $3.5 \%$ ash and $6.7 \%$ extractive and total water content of mixture $42 \%$ (dry base) [42].

\section{Scenarios description}

Via a thorough review of potential biochemical and thermochemical pathways, six fuels/chemicals were selected based on potential application, technology maturity and market demand (Table 2). Methanol and FischerTropsch (FT) liquids were investigated through the thermochemical conversion of lignocellulose to biofuels, as an alternative to biological conversion [43]. Six scenarios were included in this study, i.e. 2G bioethanol: baseline technology (scenario 1), co-production of lactic acid with ethanol (scenario 2), furfural and ethanol (scenario 3),

Table 1 Detail of available feedstock for a typical South African sugar mill

\begin{tabular}{llll}
\hline Material & Percentage & $\mathbf{t} / \mathbf{h}$ & Reference \\
\hline Sugarcane & - & 300 & {$[18,39,40]$} \\
Wet bagasse & 30\% of sugarcane & 90 & {$[18,40]$} \\
Dry bagasse $^{\mathrm{a}}$ & 50\% of wet bagasse & 45 & {$[18,39,41]$} \\
Total tops and trash $^{\text {15\% of Sugarcane }}$ & 45 & {$[18]$} \\
Trash available for biorefinery & 50\% of total residue & 22.5 & {$[18,41]$} \\
Dry trash $^{\text {a }}$ & 85\% of wet residue & $\sim 20$ & {$[18,39,41]$} \\
Total feedstock $^{\text {D DM/wet }}$ & & $65 / 113$ & \\
\hline
\end{tabular}

${ }^{a}$ Extracts are included in dry matter (DM) butanol (scenario 4), methanol (scenario 5) and FischerTropsch syncrude (scenario 6). In all scenarios, surplus electricity was produced after satisfying the operational demands of the combined sugar mill and annexed biorefinery, and was assumed to be a co-product exported to grid.

The selected biorefinery scenarios were developed under the assumption that they would be annexed to an existing South African sugar mill, where representative conditions of a typical SA sugar mills was considered. The whole system was assumed to be self-sufficient in energy, i.e. the operational energy requirement for both the sugar mill and adjacent biorefinery was met exclusively by the available lignocellulosic biomass or components thereof, without any supplementary fossil energy input. Sugarcane bagasse from the mill combined with brown leaves was simulated as the feedstock for the biorefinery, for both the Combined Heat and Power (CHP) plant and the biofuel/biochemical conversion processes. The CHP plant was assumed to replace the inefficient boiler in the existing sugar mill, providing steam and electricity to both the sugar mill and annexed biorefinery.

All of the scenarios were used to develop detailed process models covering all the key unit operations and simulated in detail using Aspen Plus ${ }^{\circledR}$ (Aspen Technology Inc., USA), which allows rigorous definition of processes, equipment and utility requirements [53]. The assumptions used for simulation of biorefinery scenarios are presented in Tables S1 and S2 of Additional file 1.

\section{Scenario 1: production of ethanol and electricity}

Steam explosion pretreatment, catalysed with sulphur dioxide $\left(\mathrm{SO}_{2}\right)$, along with simultaneous saccharification and co-fermentation $(\mathrm{SScF})$ was adopted in the process model for ethanol production, based on the promising conversion performance demonstrated in previous studies [54-57]. To minimise enzyme supply costs [58], an on-site cellulase enzyme production unit was modelled in the biorefinery simulation, based on the literature data sourced from the National Renewable Energy Laboratory [59]. The purification and recovery section was modelled to separate water, anhydrous ethanol and combustible

Table 2 Selected bio-products in the bio-based market. Adopted from [52]

\begin{tabular}{|c|c|c|c|c|c|}
\hline & Potential application & $\begin{array}{l}\text { Volume } \\
\text { (1000 t/year) }\end{array}$ & $\begin{array}{l}\text { Sales } \\
\text { (M\$/year) }\end{array}$ & $\%$ of total market & Reference \\
\hline Ethanol & Dominant biofuel, globally & 71,310 & 58,141 & 93 & [44-46] \\
\hline n-Butanol & Replacement of petroleum-derived butanol & 590 & 1115 & 20 & [47] \\
\hline Furfural & Platform chemical, conversion to petro-chemicals & $300-700$ & $300-1015$ & 100 & [48] \\
\hline Lactic acid & Multiple commodity, i.e. acrylic acid, 1,2-propanediol, pyruvic acid & 472 & 684 & 100 & [49-51] \\
\hline
\end{tabular}


solids from the fermentation broth. The produced ethanol is purified up to $92.55 \%$ wt using two distillation columns followed by a molecular sieve dehydration column to meet fuel grade ethanol (99.5\% wt purity) [60-63]. The evaporation unit was simulated not only to purify stillage water for internal recycling, but also to produce a syrup of solubles suitable for co-feeding to the boilers, along with solid residues [64-66]. Water treatment unit (Fig. 1) includes waste water treatment (WWT) and water cycle for CHP unit. In WWT, during anaerobic digestion biogas is produced and sent to CHP unit, while the treated water is recycled internally [57].

\section{Scenario 2: production of ethanol, lactic acid and electricity}

The scenario for producing lactic acid from lignocellulosic biomass included four main steps [67], i.e. pretreatment, enzymatic hydrolysis, fermentation and separation-purification. Along with the ethanol derived from the cellulose portion, lactic acid is simulated as a product from the hemicellulose fractions as illustrated in Fig. 1. These processes share a single pretreatment unit, after which the sugar streams are divided according to aforementioned bioprocesses. During the fermentation process, the produced lactic acid is continuously neutralised using $\mathrm{Mg}(\mathrm{OH})_{2}$, to minimise its inhibitory effect to the fermenting strains, forming Mg-lactate. The latter was assumed to react with a water-miscible organic amine, trimethylamine $\left(\mathrm{R}_{3} \mathrm{~N}\right)$, forming $\mathrm{Mg}(\mathrm{OH})_{2}$ crystals and a $\mathrm{R}_{3} \mathrm{~N}$-lactate complex, in an exchange reactor. The $\mathrm{Mg}(\mathrm{OH})_{2}$ crystals were filtered and recycled back to fermentation; the $\mathrm{R}_{3} \mathrm{~N}$-lactate complex was thermally decomposed to release lactic acid and the $\mathrm{R}_{3} \mathrm{~N}$ was recycled back to the exchange reactor $[68,69]$. Purification of crude lactic acid product from fermentation broth [70], in a two-step reaction process, involved the esterification of lactic acid and hydrolysis of the ester, giving the highest purity levels (99.5\% wt) [71, 72].

\section{Scenario 3: furfural, ethanol and electricity production}

In scenario 3, processes for co-generation of furfural, bioethanol and electricity were simulated, where bioethanol and furfural are derived from the cellulose and hemicellulose components, respectively [73, 74] using similar pretreatment and ethanol production processes as scenario 2 (lactic acid production; Fig. 1). In the presence of hydrochloric acid catalyst, the hemicellulose fraction obtained from pretreatment is converted to furfural, which is followed by the addition of tetrahydrofuran (THF) for furfural extraction and side reaction prevention in a two-phase reaction-separation system [48, 74, 75]. The organic solid fractions were separated from the aqueous phase by a downstream decanter, and sent to the distillation stage for product recovery. THF is separated and recycled back after the first and second furfural distillation columns, and the mixture of formic acid and acetic acid are extracted from the rest, through the third distillation column. The fourth column produces furfural with $99.8 \%$ wt purity, while the fifth column is applied to separate formic acid and acetic acid as minor side products [73].

\section{Scenario 4: co-production of butanol and electricity}

The acetone-butanol-ethanol (ABE) fermentation [76, 77] using strains of the bacterium, Clostridia, under anaerobic conditions, was modelled for butanol production from both hexose and pentose sugars [78, 79]. Dilute acid pretreatment was selected for scenario 4 , based on available experimental data in the literature, rather than steam explosion pretreatment applied for ethanol production in scenarios 1, 2 and 3 [80-82]. To avoid feed and product inhibition, simultaneous saccharification and fermentation (SSF) combined with gas stripping was selected for hydrolysis-fermentation of pretreated lignocellulose, where the medium for gas stripping and mixing in the fermenters was modelled as fermentation gases $\left(\mathrm{CO}_{2}\right.$ and $\left.\mathrm{H}_{2}\right)$ [82]. The $\mathrm{ABE}$ products are recovered from the gas by condensation at $0{ }^{\circ} \mathrm{C}$ via a cryogenic cycle, followed by further purification [82, 83]. Liquid-liquid extraction was simulated to separate butanol, ethanol and acetone from the condensate, followed by conventional distillation to purify butanol to $99.5 \% \mathrm{wt}$ (main product), along with ethanol and acetone (side products) [84].

\section{Scenario 5: production of methanol and electricity}

Allothermal gasification (ALO-G) was modelled for syngas production from sugarcane lignocelluloses [85], in which the heat for the endothermic gasification reactions was assumed to be supplied by a heat transfer medium, such as a bed material circulated between combustion and gasification chambers in a dual fluidised bed gasifier [86-88]. The gasification conditions for very low-tar syngas production were simulated [85]. Separated from the bed material after gasification process [89], the syngas undergoes cooling (Fig. 2), and conditioning, where $\mathrm{CO}_{2}$ and $\mathrm{H}_{2} \mathrm{~S}$ are removed from the syngas in the Rectisol unit [90, 91]. Once cleaned and conditioned, the syngas is compressed to 98 bar (liquid phase) and converted to methanol in a fixed bed synthesis reactor [92]. The reactor feed is pre-heated to the reaction temperature of $250{ }^{\circ} \mathrm{C}$, which is isothermally maintained by steam generation, while cooling of the reactor effluent is achieved by heating up the reactor feed directly through a double fluid heat exchanger. The vapour phase product from the single-pass synthesis reactor is cooled down to recover the methanol and separate unconverted syngas and inert gaseous species $\left(\mathrm{CO}_{2}, \mathrm{CH}_{4}\right)$ [93]. The combined 


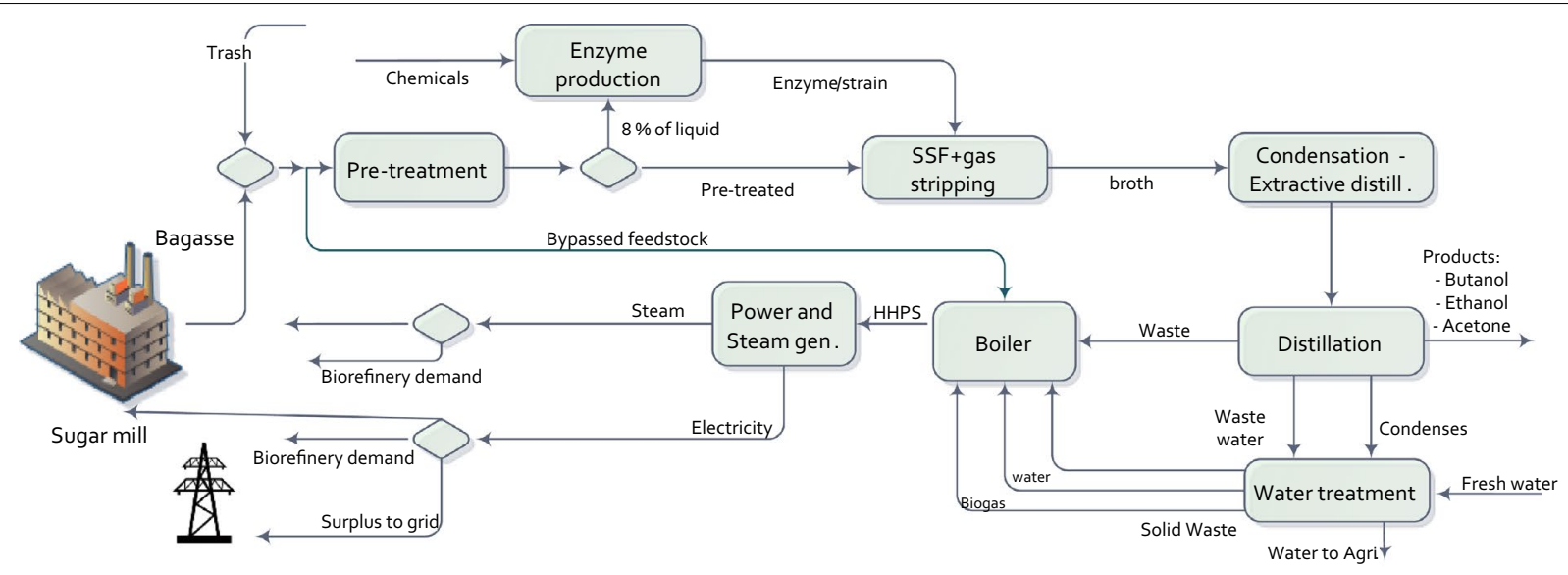

Scenario 4: Butanol production

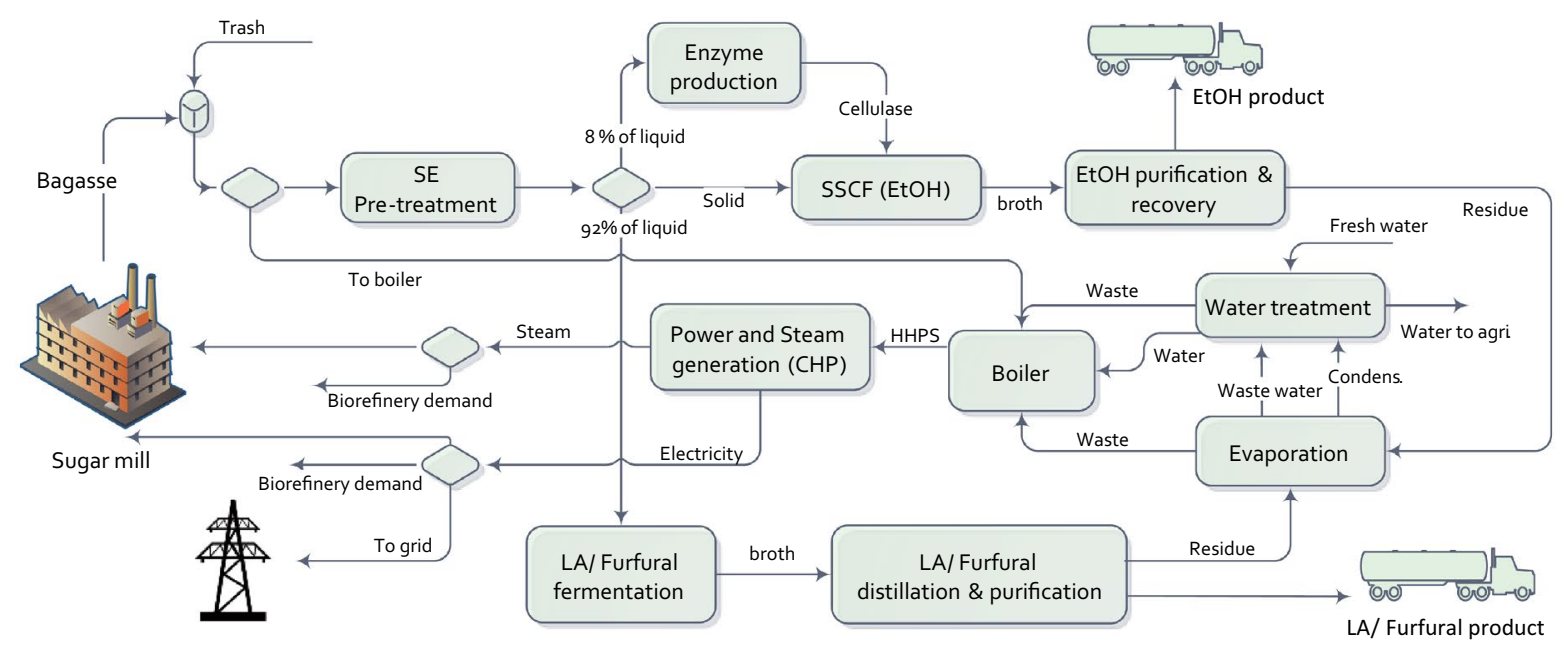

Scenarios 2/3: Ethanol from cellulose and LA/furfural form hemicellulose

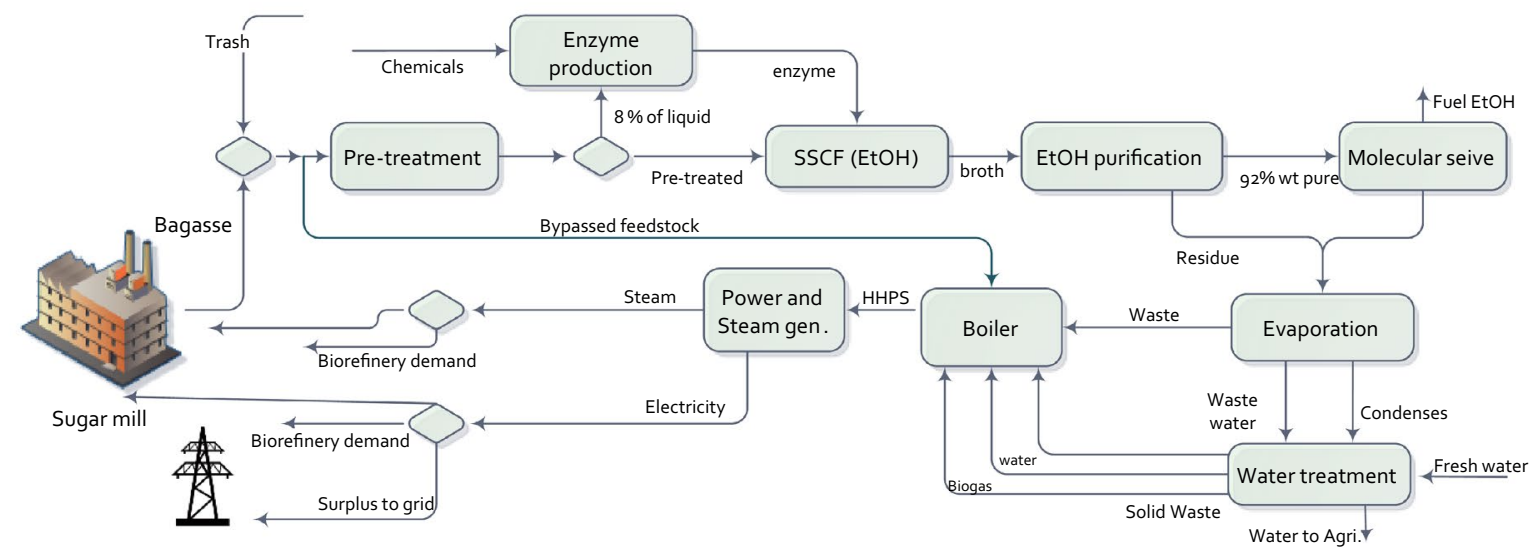

Scenario 1: Ethanol production

Fig. 1 Block flow diagram of the biochemical scenarios 


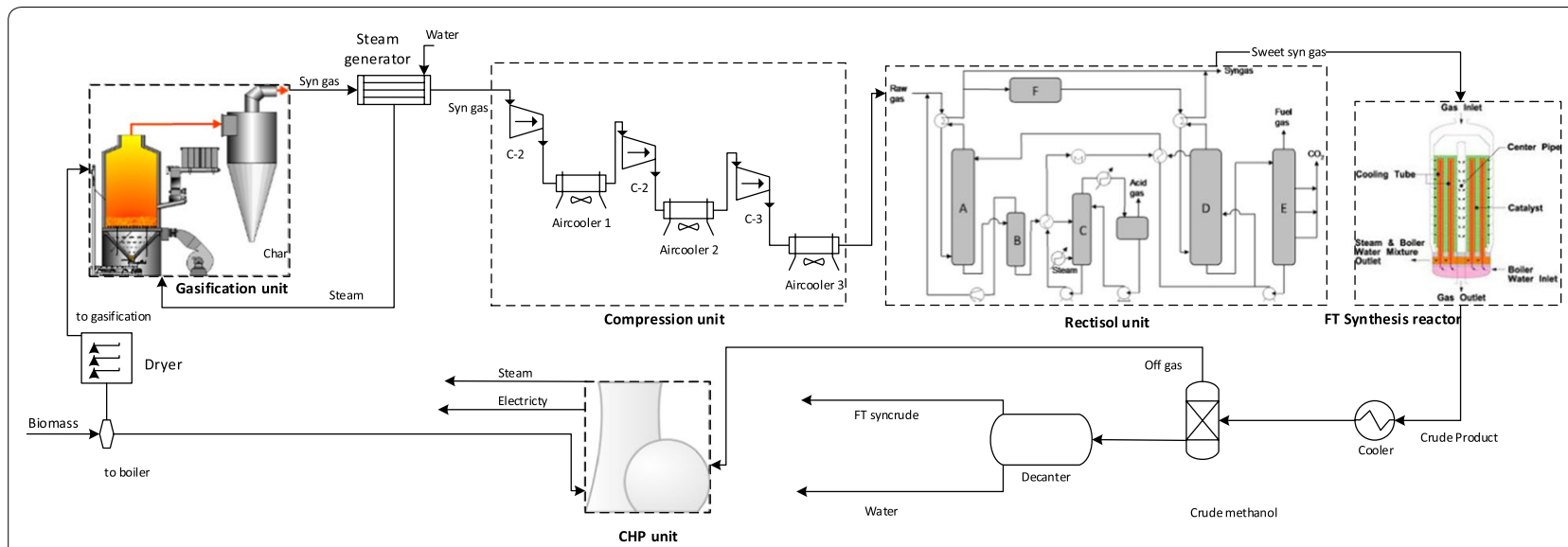

Scenario 6: FT Syncrude production

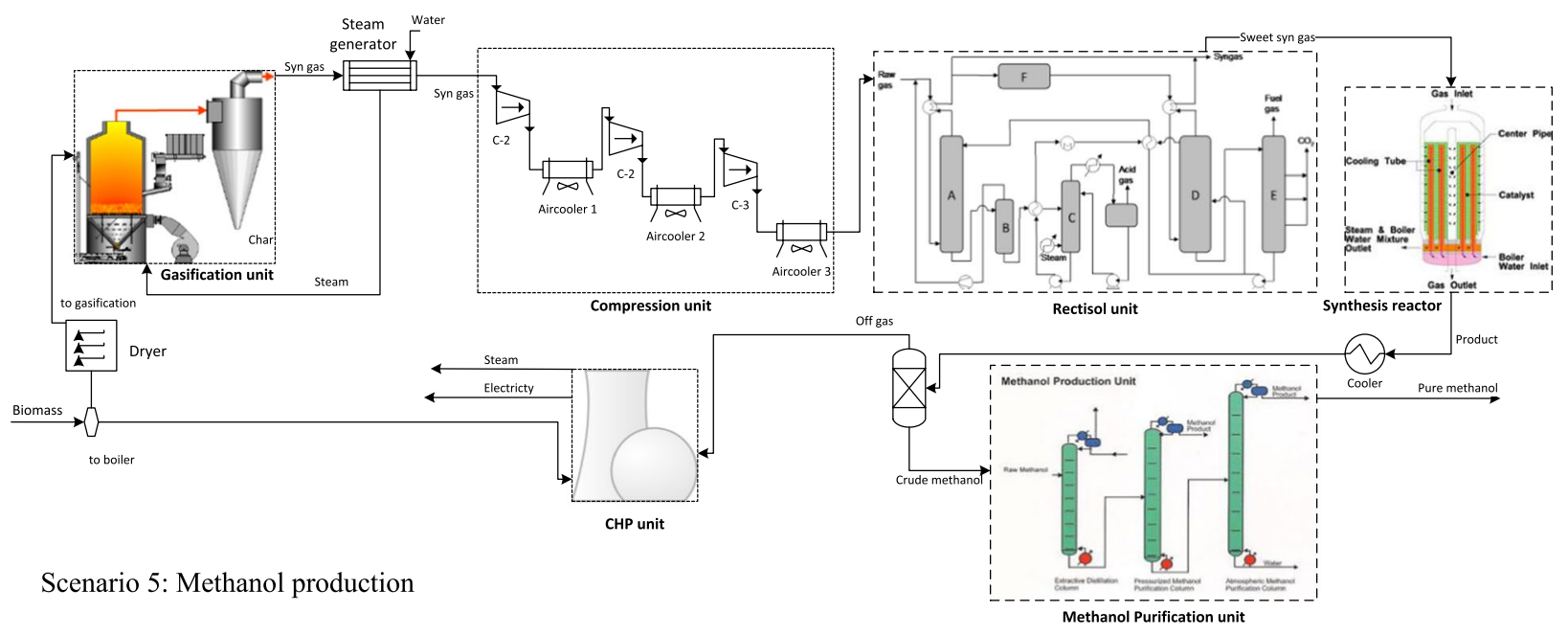

Fig. 2 Block flow diagram of the thermochemical scenarios

gas streams are heated before expansion through a turbo expander generator to recover some of the compression energy of the gas by generating electricity [85].

\section{Scenario 6: production of syncrude and electricity via Fischer- Tropsch synthesis (FTS)}

Under scenario 6 , the conditioned syngas derived from scenario 5 was assumed to be converted to FischerTropsch (FT) syncrude in a low-temperature reactor [94]. Under an advanced FT synthesis process, high-pressure reactor conditions allow the wax products existing in liquid phase (with catalyst suspended) to be removed from the bottom of the reactor. Since the reaction heat is rapidly dispensed through the liquid medium to a cooling medium, a syngas conversion of up to $90 \%$ per pass is possible [95]. An equal distribution between the four primary hydrocarbons product types (i.e. gases, naphtha, diesel and waxes) was assumed [96], with an occurrence probability of $90 \%$, following the trends of AndersonSchulz-Flory [94].

\section{Economic assessments}

An economic assessment was implemented using Aspen Plus ${ }^{\circledR}$ Economic Evaluator and literature data to estimate the purchased and installed cost of equipment and variable and fixed operating costs, based on technical information obtained from process simulations [97]. Internal rate of return (IRR) was adopted as the indicator of investment feasibility. The operational costs were categorised as variable operating costs (the cost of feedstock, chemicals and disposal waste) and fixed operating costs (fixed cost of the plant independent of production capacity, including labour costs, maintenance, and property insurance and tax) [97]. The economic parameters specific to South Africa were selected for the economic evaluation in this study and are presented in Table 3. 
Table 3 Parameters of the economic analysis, based on South Africa

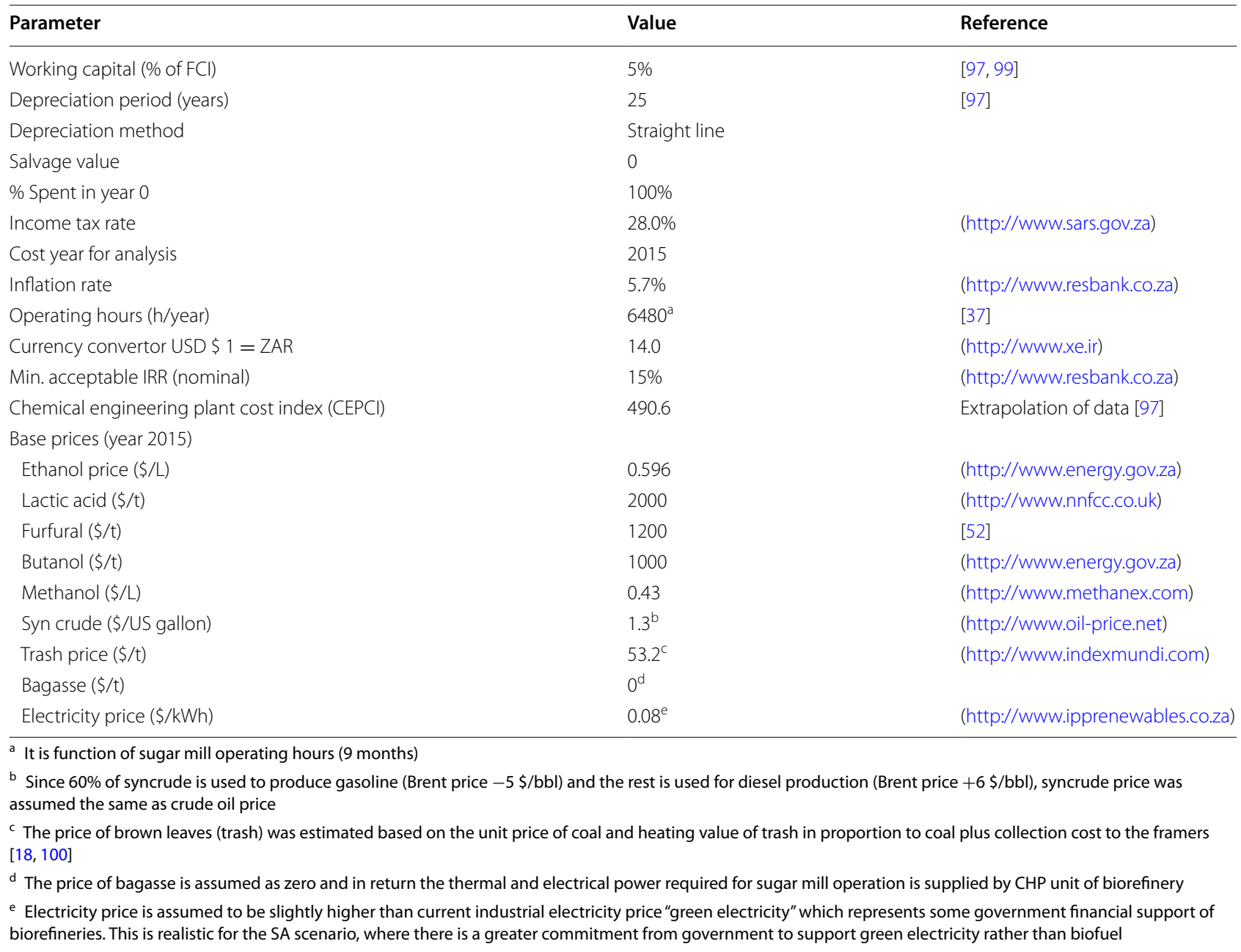

The cost of the bagasse from the sugar mill was assumed to be of equivalent economic value as the steam and electricity provided back to the sugar mill by the CHP plant. It worth noting that subsidies and direct financial support from government were excluded from the analyses under the current study as a stringent approach to identify opportunities that are economically viable for expanding the bio-sector under the developing country context, where less governmental financial support would be available compared with the well-subsidised biosectors in the developed world $[7,98]$.

\section{LCA methodologies}

\section{Model systems and functional unit}

In this study, an attributional life cycle assessment (aLCA) approach was applied to evaluate the environmental viability of $2 \mathrm{G}$ biorefinery designs for the conversion of sugarcane residues to a range of fuels and biochemicals via thermochemical and/or biochemical routes. As illustrated in Fig. 3, production pathways for bioethanol, biobutanol, lactic acid, furfural, biomethanol, syncrude derived from sugarcane bagasse and trash are included in the LCA system boundary. The LCA system boundary (Fig. 3) includes production of investigated products, i.e. bioethanol, methanol, lactic acid, etc., from sugarcane bagasse and trash, as well as sugarcane cultivation, harvesting, transportation and bagasse production in the sugar mill (the residue of sugar production process).

The LCA study aimed to provide insights into the environmentally sustainable pathways for sugarcane residue utilisation and 'hot-spot' identification (i.e. main environmental contributors) for each cradle-to-biorefinery-gate system. The functional unit was defined as "a biorefinery with the capacity of processing $65(\mathrm{tDM} / \mathrm{h})$ tonnes bagasse and trash per hour". 


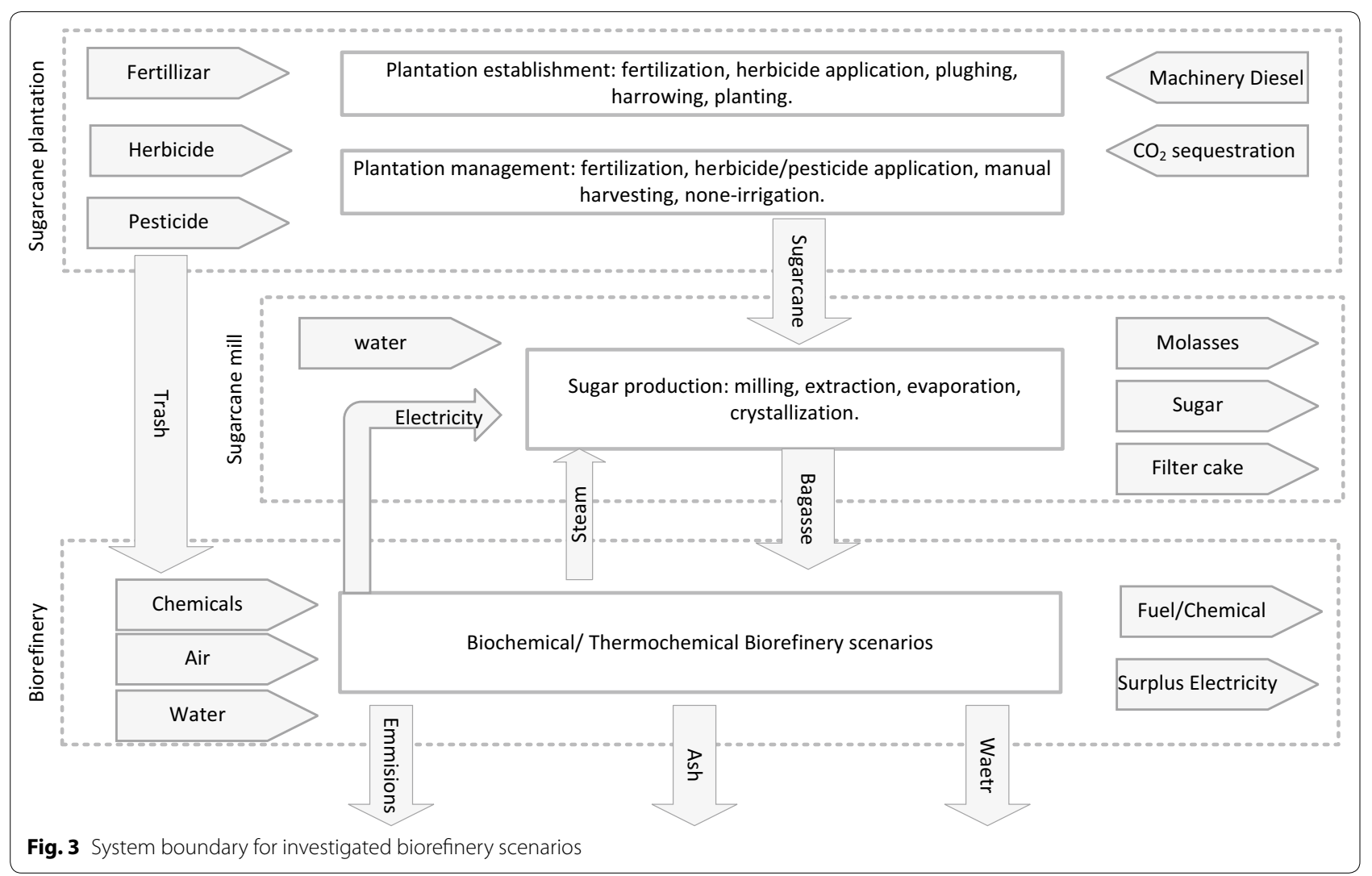

\section{Allocation approach}

Based on ISO guideline [101], different allocation approaches have been considered. Under the current study, allocation procedure is not avoidable for unit-processes generating multiple co-products, e.g. sugar mill producing sugar, molasses, bagasse and filter cake. Moreover, allocation by physical relationships (either mass or energy content) cannot reflect the underlying relationships between the co-products under an economic valuedriven multi-product system. Thus for multi-output systems, an economic allocation approach was used as a default method to partition the input-output flows and environmental burdens according to the respective value and quantity of co-products. An alternative allocation approach recommended by EU Renewable Energy Directive [102] - energy allocation, where the environmental burdens were allocated amongst the co-products (e.g. bioethanol and lactic acid) based on their energy contents-was applied in the sensitivity analysis.

A stoichiometric carbon-counting approach was used to 'track' the carbon flows from sugarcane residue into bio-products over the cradle-to-biorefinery-gate life cycle. Other carbon flows (e.g. fermentation emissions, etc.) were assumed to be as $\mathrm{CO}_{2}$ and were therefore treated as carbon-neutral. This C-counting approach with regard to the bio-products was applied to determine (1) carbon 'sequestration' into the bio-products (from the sugarcane cultivation phase of the life cycle) and (2) downstream release of this carbon during the subsequent processing stages of the bio-product life cycle. The sequestration of carbon into biomass during the cane growth phase thus represents a 'negative' GHG emission at this life cycle stage but this carbon could then be returned to the environment in various ways depending upon the subsequent fate of the products. In current study, we assumed soil carbon as steady state, i.e. no soil carbon accumulation or change in mid-term due to the carbon-neutral balance between below-ground biomass degradation and $\mathrm{CO}_{2}$ emissions from soil organic matter turnover. However, the below-ground soil carbon turnover and the carbon cycling in cane-soil ecosystems can be simulated using biogeochemical modelling approach, which is driven by climate, soil properties, planation management and anthropogenic activity [103, 104]. Such detailed simulation can be included in future studies. A schematic diagram of carbon flows through a representative biorefinery is depicted in Figure S1 of Additional file 1. 


\section{Life cycle inventory, impact assessments and data quality analysis}

Complete inventories for the life cycle of sugarcane residue-derived bio-products were developed by combining simulation results of advanced $2 \mathrm{G}$ biorefineries (in particular, detailed material and energy balances) and literature data representing sugarcane cultivation in South Africa and sugar mill processing technology $[105,106]$. The inventory of sugarcane cultivation and sugar milling is presented in Tables S5 and S6 of Additional file 1, respectively.

Life cycle impact assessment (LCIA) methodologies can be categorised as midpoint- and endpoint-oriented approaches which are also termed as 'problem-oriented' and 'damage approach', respectively. The former is chosen along with environmental mechanisms between the life cycle inventory (LCI) results and endpoints [107] and the latter is defined at the level of protection area [108]. Two midpoint approaches developed by the Centre of Environmental Science (CML) of Leiden University and Technische Universitat Berlin, respectively-CML-IA baseline 3.02 and water scarcity [109] - were applied as default characterisation methods in this study at the LCIA stage where the evaluation focused on 12 impact categories, viz. abiotic depletion, global warming potential (GWP100), acidification, eutrophication, ozone depletion (ODP) and photochemical oxidation (POCP), terrestrial, aquatic eco-toxicity and human toxicity, water consumption and water scarcity. Damage-oriented approaches were applied to sensitivity analyses, i.e. Eco-Indicator 99 hierarchist version (EI 99H/A) and pfitzer Eco-indicator 99 (Water footprint) defining impact categories at the endpoint level. A scenario sensitivity analysis method was used to examine the sensitivity of the LCA findings to the LCIA methodological choice [110]. A 10\% change in the characterised LCIA profiles for a single product system or a reversal of the rank order of the LCA comparisons was chosen as sensitivity thresholds above which the influence of LCIA method was considered to be significant. The LCA model was implemented in Simapro 8.0.4.30 (PRe Consultants 2014).

\section{Results and discussion}

\section{Overall mass and energy balance}

The overall mass and energy balances (heating, cooling and power demand) of the simulated biorefinery scenarios are presented in Table 4, where the bypass of the feedstock required for the CHP unit varied with the energy balances of individual scenarios. These were in agreement with previous reports, showing the need to combust a portion of the unprocessed lignocellulose feedstock to meet the energy demands of the integrated sugar mill-biorefinery processes [111]. The highest bypass requirement (58 $\mathrm{wt} \%$ ) was for the co-production of furfural and ethanol, which can be attributed to the high steam demand for separating THF from the reaction mixture and the significant amount of THF inputs as feed in the two-phase production system.

FT synthesis demonstrated the highest lignocellulosic biomass availability for process conversion $(70 \%$ of the total feed; $30 \%$ bypass), primarily benefiting from the exclusion of the energy costs of syncrude purification in scenario 6. The energy requirement per unit of biomass is presented in Fig. 4 for all the scenarios. Butanol production showed the highest electrical power and cooling demands due to the cryogenic requirements of the gasstripping process, while furfural was the most energyintensive process particularly with heating demand, because of the steam requirement for furfural recovery and purification.

As represented in Table 4, scenario 2 demonstrated a superior total production rate to scenario 1 but lower electricity generation. It can be ascribed to the fact that the reaction of sugars to ethanol is a hetero-fermentative process with $\mathrm{CO}_{2}$ as by-product, while LA production from sugars is homo-fermentative process without carbon-containing by-products [112]. As a result, during fermentation of the liquid fraction after pretreatment, xylose was converted to LA with a higher conversion (91\% of the theoretical maximum of $1 \mathrm{~g} / \mathrm{g}$ ) [49], than xylose to ethanol $(76.6 \%$ of the theoretical maximum of $0.51 \mathrm{~g} / \mathrm{g})$. Scenario 3 showed better biomass conversion efficiency than scenario $1[0.29$ and $0.26(\mathrm{t} / \mathrm{t})$, respectively], due to a more favourable xylose conversion pathway to furfural (85\%) [73] than to ethanol (76.6\%) [113]. However, a lower total biochemical production rate $(92.2$ $\mathrm{t} / \mathrm{h}$ ) was observed in scenario 3 in comparison with scenarios 1 and 2, because of its low proportion of biomass available for biorefinery processes after meeting CHP needs (high lignocellulose bypass to the boiler).

Due to the less efficient conversion from glucose and xylose to butanol (56 and 20\%, respectively [114]) compared to ethanol, furfural and lactic acid production, scenario 4 turned out to be an inferior system with the lowest biochemical production rate amongst all simulated routes.

Although the production yield of methanol (scenario 5) and ethanol-LA (scenario 2) was broadly similar $(0.302$ and $0.311 \mathrm{t} / \mathrm{t}$, respectively), scenario 5 showed a higher biochemical production (12.76 vs. $11 \mathrm{t} / \mathrm{h})$, but significantly lower electricity outputs $(0.5$ vs. $7 \mathrm{MW})$ than scenario 1 . This could be explained by (1) the large amount of unconverted hydrocarbon residues (lignin and unconverted cellulose and hemicellulose) and the resulting high power export potential for biochemical processes [39], compared to the thermochemical routes, where both the 
Table 4 Overall mass and energy balance of the studied biorefinery scenarios

\begin{tabular}{|c|c|c|c|c|c|c|c|}
\hline & Unit & $\begin{array}{l}\text { Scenario } 1 \\
\text { EtOH }\end{array}$ & $\begin{array}{l}\text { Scenario } 2 \\
\text { EtOH-LA }\end{array}$ & $\begin{array}{l}\text { Scenario } 3 \\
\text { EtOH-Fur. }\end{array}$ & $\begin{array}{l}\text { Scenario } 4 \\
\text { Butanol }\end{array}$ & $\begin{array}{l}\text { Scenario } 5 \\
\text { Methanol }\end{array}$ & $\begin{array}{l}\text { Scenario } 6 \\
\text { FT syncrude }\end{array}$ \\
\hline \multicolumn{8}{|l|}{ Feedstock } \\
\hline \multirow[t]{2}{*}{ Bypass to boiler } & $\mathrm{t} / \mathrm{h}$ & 22.75 & 26.00 & 32.50 & 26.00 & 22.75 & 19.50 \\
\hline & $\%$ & 35.00 & 40.00 & 50.00 & 40.00 & 35.00 & 30.00 \\
\hline To biorefinery & $\mathrm{t} / \mathrm{h}$ & 42.25 & 39.00 & 32.25 & 39.00 & 42.25 & 45.50 \\
\hline \multicolumn{8}{|l|}{ Products } \\
\hline Ethanol & $\mathrm{t} / \mathrm{h}$ & 11.00 & 7.48 & 5.66 & 0.35 & - & - \\
\hline Lactic acid & $\mathrm{t} / \mathrm{h}$ & - & 4.65 & - & - & - & - \\
\hline Furfural & $\mathrm{t} / \mathrm{h}$ & - & - & 2.07 & - & - & - \\
\hline Butanol & $\mathrm{t} / \mathrm{h}$ & - & - & - & 4.61 & - & - \\
\hline Methanol & $\mathrm{t} / \mathrm{h}$ & - & - & - & - & 12.76 & - \\
\hline Syncrude & $\mathrm{t} / \mathrm{h}$ & - & - & - & - & - & $5.80^{e}$ \\
\hline Acetone & $\mathrm{t} / \mathrm{h}$ & - & - & - & 1.50 & - & - \\
\hline Acetic acid & $t / h$ & - & - & 1.25 & - & - & - \\
\hline Surplus elc. & MW & 7.10 & 5.60 & 7.50 & 4.30 & 0.50 & 1.80 \\
\hline \multirow[t]{2}{*}{ Total production ${ }^{\mathrm{a}}$} & $\mathrm{t} / \mathrm{h}$ & 11.00 & 12.13 & $9.22^{c}$ & 6.46 & 12.76 & 5.80 \\
\hline & $t / t^{d}$ & 0.26 & 0.31 & 0.29 & 0.16 & 0.30 & 0.13 \\
\hline \multicolumn{8}{|l|}{ Energy demand ${ }^{b}$} \\
\hline Cooling & MW & 50.70 & 45.50 & 52.00 & 73.10 & 26.20 & 33.90 \\
\hline Heating & MW & 69.10 & 66.60 & 66.30 & 61.70 & 2.60 & 2.40 \\
\hline Power & MW & 2.00 & 2.00 & 2.30 & 13.70 & 14.20 & 13.70 \\
\hline
\end{tabular}

a Total production of chemicals

b Heat and power demand of sugar mill is excluded

c Produced formic acid is included

d Production yield: tonne of product(s) per tonne of biomass fed to biorefinery "exclusive of feedstock bypassed to CHP"

e Density of syncrude $=634.8 \mathrm{~kg} / \mathrm{m}^{3}$

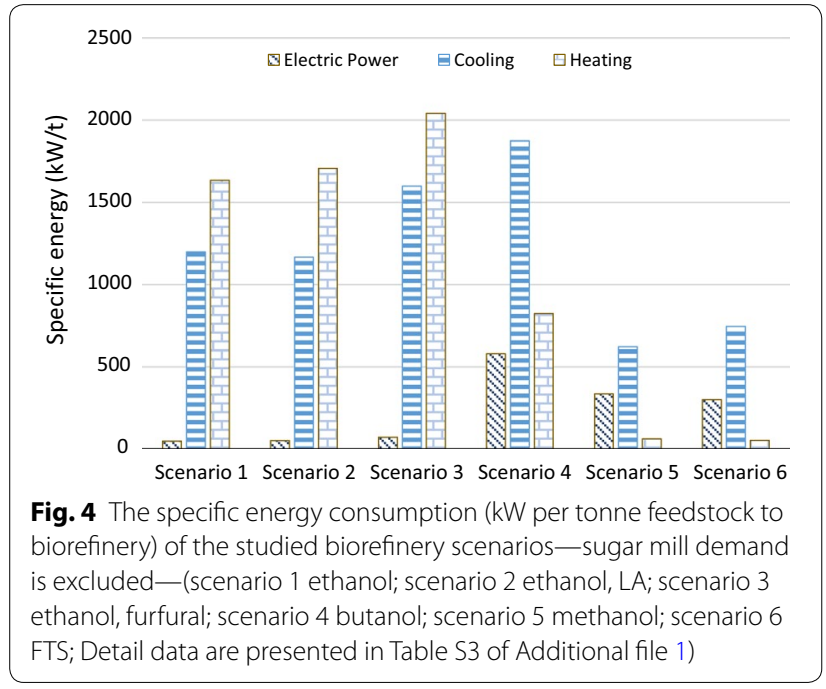

lignin and carbohydrate components of lignocelluloses are converted to fuels/chemicals products, and (2) high electrical power demands for operating compressors and air-cooler fans (syngas purification) in gasification scenarios [99].

Methanol production represented the superior thermochemical route with better technical performance than FT synthesis, which was mainly driven by their different overall biomass conversion rates. Although the same processes were modelled for syngas production and conditioning in scenarios 5 and 6 , the energy content of methanol fuel from syngas was $37.1 \%$ higher than for the FT synthesis [85]. This could be explained by the fundamental reactions for methanol $\left(\mathrm{CO}+2 \mathrm{H}_{2} \rightarrow \mathrm{CH}_{3} \mathrm{OH}\right)$ and FT liquid production $\left(\mathrm{CO}+2 \mathrm{H}_{2} \rightarrow-\mathrm{CH} 2-+\mathrm{H}_{2} \mathrm{O}\right)$, which demonstrate that the water formation in FT synthesis results in a loss of chemical energy [115]. In addition, biomethanol and FT syncrude differ in their fuel quality and applicability as drop-in biofuels. Mixtures of methanol and gasoline have been already launched in the market. In China, national fuel blending standards of M85 (85\% methanol, 15\% gasoline) and M100 (100\% methanol) has been developed since 2009, and M15 standard is in progress [116, 117]. Therefore, produced methanol can be used as drop-in fuel. While the 
produced syncrude needs more deoxygenation and upgrading processes to derive different fuels, i.e. diesel, gasoline, jet fuel $[85,118]$, it cannot be used as fuel in the current format. Such biofuel quality aspect is out of current study scope but can be further discussed in future research.

\section{A comparison of the economic viability}

The calculated total capital investment (TCI), operating costs (OPEX), total sales and IRR for all the scenarios are presented in Table 5. The installed costs of the biochemical biorefinery scenarios excluding the CHP plant are given in Fig. 5.

The simulations presented in the current study were regarded as representative of industrial scale production. The bioethanol production capacity of scenario 1 [90.4 million litre per year (ML/year)] compared well with commercial lignocellulosic bioethanol plants (e.g. Abengoa plant with capacity of $90 \mathrm{ML} /$ year [119]), whereas the estimated TCI of $\$ 2.66 / \mathrm{L}$ also agreed with the reported industrial data $\$ 2.64 / \mathrm{L}$ (Abengoa Hugoton Project, USA; http://www.abengoa.com), \$2.65/L Beta Renewables

Table 5 Concise results of economic evaluation for studied scenarios

\begin{tabular}{|c|c|c|c|c|c|}
\hline & $\begin{array}{l}\mathrm{TCl} \\
(\text { million } \$)^{\mathrm{a}}\end{array}$ & $\begin{array}{l}\text { Fixed operating cost } \\
\text { (million } \$ / \text { year) }\end{array}$ & $\begin{array}{l}\text { Variable operating cost } \\
\text { (million } \$ / \text { year) }^{\mathbf{b}}\end{array}$ & $\begin{array}{l}\text { Total sales } \\
\text { (million } \$ / \text { year) }^{\mathbf{b}}\end{array}$ & IRR \% \\
\hline Scenario 1 & 240 & 8.1 & 10.2 & 58.6 & 14.7 \\
\hline Scenario 2 & 288 & 9.5 & 24.4 & 99.5 & 20.5 \\
\hline Scenario 3 & 321 & 10.8 & 16.0 & 54.1 & 7.5 \\
\hline Scenario 4 & 269 & 5.8 & 17.2 & 40.2 & 4.8 \\
\hline Scenario 5 & 233 & 8.5 & 7.9 & 56.5 & 16.7 \\
\hline Scenario 6 & 234 & 8.1 & 8.2 & 12.6 & 11.5 \\
\hline
\end{tabular}

a Total Capital Investment (TCI). The boiler and power generation sections contributing approximately $20-25 \%$ of the TCI (\$60-64 million)

b First year of economic analysis (2015)

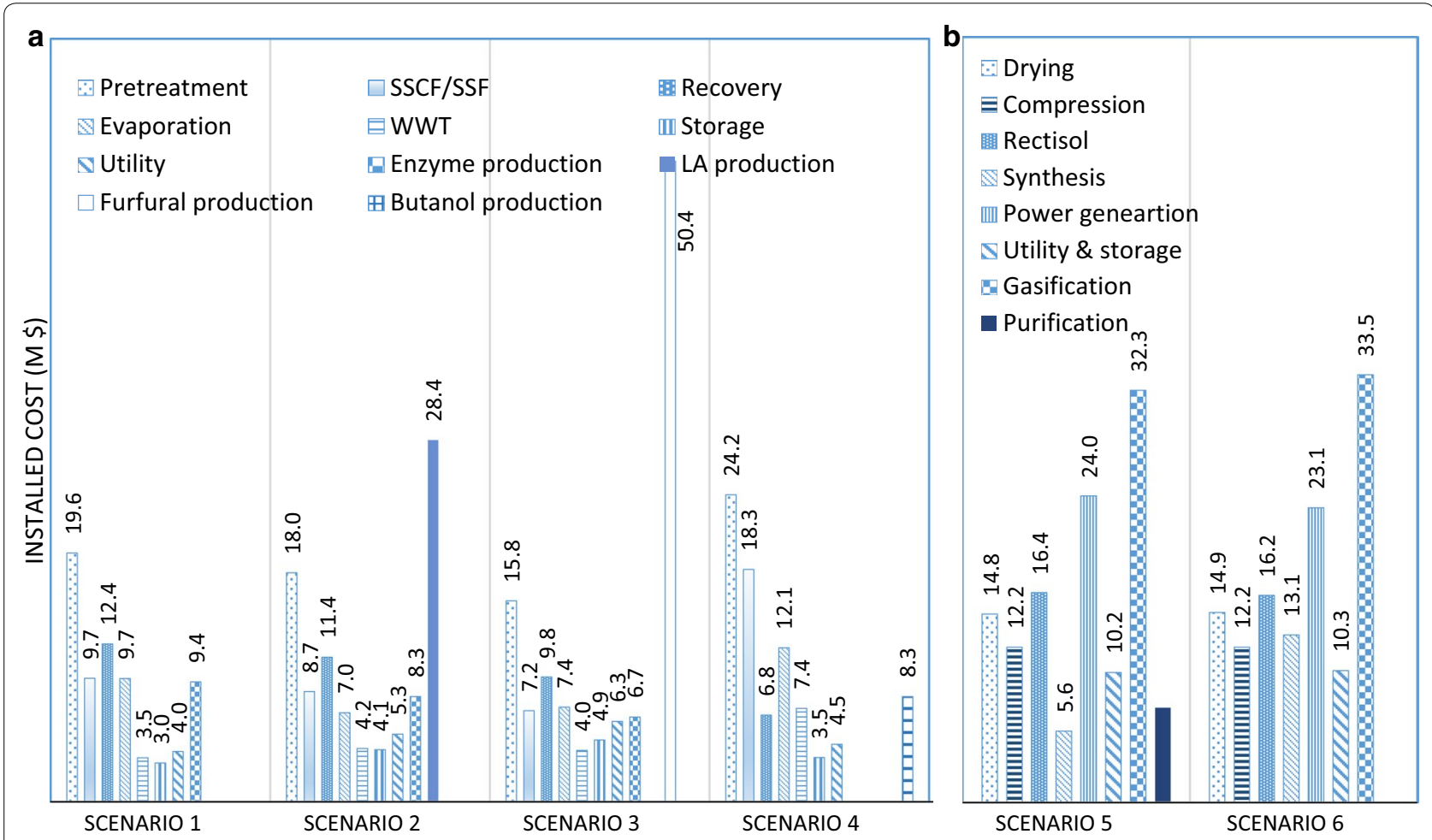

Fig. 5 Detailed installed cost of the biochemical biorefinery scenarios (CHP is excluded which costs \$61-63.1 million) (a biochemical scenarios, b thermochemical scenarios) 
(Italy; http://www.betarenewables.com), \$2.52/L Iogen Costa Pinto Project (Brazil; http://www.iogen.ca). The simulation of the biomethanol scenario was comparable with the ongoing commercial scale plants such as Varmlands Methanol in Sweden (production capacity: 92,000 t/year, TCI: \$290 million) and Woodsprit Projects in Netherlands (production capacity: 413,000 t/year, TCI: $\$ 550$ million) [120].

Comparison of scenarios 1, 2 and 3 indicated that the required TCI may increase with product diversification. The TCIs of the ethanol production sections in scenarios 2 and 3 were lower than scenario 1 (ethanol only), due to diversion of the hemicellulose component to lactic acid or furfural production. However, additional capital expenses were incurred for the production of lactic acid and furfural (scenarios 2 and 3), increasing the total capital cost by $\$ 48$ million ( $20.0 \%$ of TCI) and $\$ 61$ million ( $25.4 \%$ of TCI), respectively. The furfural reactor is particularly expensive, due to the high pressure (55 bar) and acid corrosion accounted for in the design of the two-phase system. We note that integration of first- and second-generation (1G2G) fermentation-based technology for bioethanol production has been demonstrated to be cheaper than a standalone 2G biorefinery [121]. However, evaluation of the 1G2G scenarios for ethanol and lactic acid production was not in the scope of this study (in all cases the sugar products are not converted further) and will be presented in future work.

Our analyses demonstrated research findings which are consistent with previous studies, i.e. butanol production by fermentation is economically uncompetitive and technically challenging compared to bioethanol production $[3,122]$. Furthermore, dilute acid pretreatment is more energy intensive than steam explosion [123], thus requiring a larger energy supply, which resulted in a higher TCI for butanol production than ethanol production.

The TCI of the gasification scenarios, measured by installed costs [approximately $\$ 123$ million, including the CHP plant (Fig. 5b)], was lower than the biochemical processes [installed cost ranges from $\$ 132$ to 174 million; Fig. 5a). Previous reports have also indicated that some thermochemical pathways may be economically more favourable than the biochemical routes [39, 124], with the advantage of ability to accommodate more a diverse range of biomass and the avoidance of large water flows in many process steps [125]. However, a comparison study of bioethanol production through biochemical and thermochemical pathways revealed that the biochemical route is presently the leading process strategy in the US and EU [119], whereas the overall economics of the two processes are broadly similar $[121,126,127]$. Determination of the most desirable pathway between thermochemical and biochemical conversion routes has been quite controversial. In general, bioethanol production through biochemical pathway seems the more preferred route in US, while the EU projects are almost equally distributed between biochemical and thermochemical conversion platforms [128]. Thermochemical conversion processes have been ordered according to increasing lowest capital cost, i.e. hydrogen, methanol, lignocellulosic ethanol and FT diesel [129]. However, in this study FT synthesis was simulated for syncrude production rather than diesel, gasoline or jet fuel, thus leading to similar TCIs for the gasification scenarios. In this context, the better performance of methanol production over the FT synthesis was partly due to better market price of methanol over syncrude, with the price of the latter closely linked to crude oil.

Scenarios 2 and 5 were found to be the most economically profitable scenarios, considering the revenue (Fig. 6). As a result of a higher methanol production rate compared to ethanol, scenario 5 had a higher revenue than scenario 1 , but lower than scenario $2(61 \%$ of its revenue derived from LA). Of all the products considered, electricity delivered the lowest contribution to the revenue (less than 5\%). Furfural co-production with ethanol did not improve the economic viability of the baseline biorefinery as it has lower total sales compared to scenario 1, with $30 \%$ of revenue derived from furfural and $53 \%$ from the ethanol sales. As stated in other studies, modern furfural commercial production is inefficient (25-35 tonne steam consumption per tonne of produced furfural) and suffers from low yields $(<50 \mathrm{~mol} \%$ of theoretical) [48]. This was avoided to some extent in our simulations and analyses by selection of an indirect, two-phase system for co-production of furfural and ethanol from lignocelluloses. Further research efforts should be placed to improve furfural yields, including the removal of furfural into the vapour phase, the extraction of furfural from the catalytically active aqueous phase using biphasic solvent systems and the application of

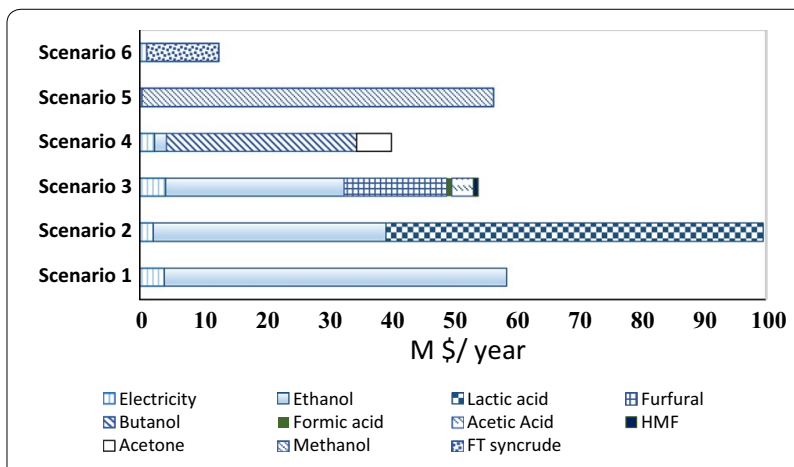

Fig. 6 Detailed sales of the studied scenarios based on the products (relevant data are given in Table $\mathbf{S 4}$ of Additional file 1) 
reusable or recoverable solid catalysts [48]. Alternatively, scenarios for direct furfural production from lignocellulose, with co-production of ethanol from solid residues, should be simulated in the future, pending availability of experimental data to describe the performance of these processes.

The ethanol-LA (scenario 2; IRR 20.5\%) and methanol synthesis (scenario 5; IRR 16.7\%) were the only scenarios with an IRR greater than the minimum expected return on investment of $15 \%$ in South Africa. Amongst all scenarios, the synthesis of methanol represented a promising system with reasonable investment potential (high IRR combined with low TCI). Scenario 2 demonstrated that an increase in the investment potential for cellulosic ethanol production could be achieved by co-producing lactic acid, whereas scenario 3 showed reversed trends with decreased investment potential by incorporating furfural co-production into bioethanol biorefineries.

\section{Sensitivity analysis for economic viability}

A sensitivity analysis was conducted to test how sensitive the economic viability is to variability in input data. The electricity price was eliminated from the sensitivity analysis due to its insignificant contribution to revenue, whereas the price of brown leaf as a harvesting residue was accounted for in the analyses as an embedded factor in the variable operating cost. As given in Fig. 7, the product prices, together with the fixed operating costs and $\mathrm{TCI}$, produced the most significant impacts on the economic evaluation.

The results of the sensitivity analysis (Fig. 7) indicated that product price had the most significant effect on IRR values, with scenarios 5, 6 and 1 showing the highest sensitivity to product price, respectively. The profitability of scenario 6 was sensitive to FT syncrude price (estimated based on crude oil data) as a $25 \%$ increase in syncrude price leads to a profitable case. However, such a finding represents a conservative estimation due to the current low oil price.

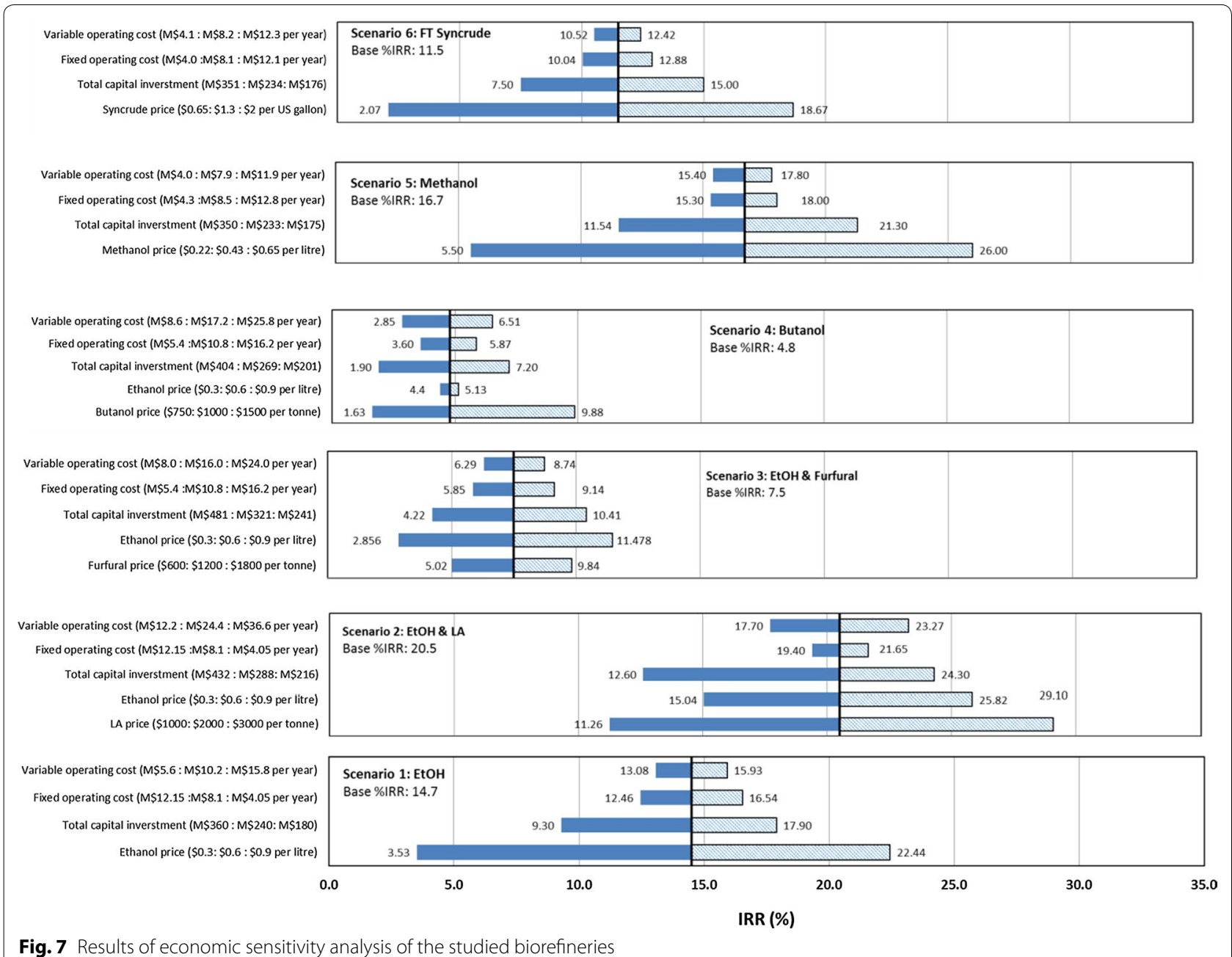

Fig. 7 Results of economic sensitivity analysis of the studied biorefineries 
As demonstrated in Fig. 7, another key parameter for IRR was TCI; scenarios 2 and 5 can meet the minimum profitability criteria (IRR of $15 \%$ ) with $25 \%$ increase in the TCI. In general, variable and fixed OPEX were not key factors, although the feedstock cost have an exceptional impact on the economic viability of biorefineries [130132]. In the annexed biorefinery case studies, the bagasse is represented as an internal material flow without counting its traded price (other than value of steam and electricity supplied back to the sugar mill at no internal cost), while only the trash price was accounted for in the OPEX. Overall, scenarios 2 and 5 presented robust cases, with a $25 \%$ decrease in the lactic acid price or a $50 \%$ drop in ethanol price; scenario 2 was still profitable; scenario 5 retained profitability potential with a $20 \%$ reduction in the methanol price. Generally, polygeneration leads to a more flexible scenario with regard to changes of market demand [133].

The revenue of the furfural production scenario is largely driven by the ethanol price $(53 \%$ revenue from bioethanol sales), leading to a case with low investment potential; it can be economically viable only if the ethanol price increases by approximately $75 \%$, or a significantly lower-cost production method is selected. Conversely, the investment potential of scenario 2 is not influenced by the ethanol revenue, but rather by lactic acid, which is caused by the dominance of lactic acid income (61\%) in the total revenue.

\section{Environmental evaluation}

The results for all LCA impact categories and normalised comparisons (\%) are presented in Figs. 8, 9, 10, 11, 12. The LCIA scores for each individual impact category and scenarios are given in Additional file 1 (Tables S8-S16).

\section{Cradle-to-biorefinery-gate LCA contribution analysis}

The environmental profiles of biofuel and biochemical production via different scenarios are given in Fig. 8. The results implied that the environmental benefits of biobased products varied significantly with scenarios. In general, the main contributors to environmental impacts were agrochemical production (herbicides, N/P fertilisers, diesel consumption) and combustion stages (emissions and ash released) in all of the scenarios, except for scenario 3, where furfural production stage (THF, $\mathrm{NaCl}$ and $\mathrm{HCl}$ consumption) dominated the environmental impacts. The chemical production processes, which varied with scenarios, were important drivers of the differences between the environmental profiles of biorefinery scenarios. However, since the unit of bagasse processed in biorefinery has been defined as the functional unit, agricultural inputs were broadly similar within scenarios. Nitrogen fertilisers played an important role in the LCIA impacts of biomass cultivation, which resulted in $\mathrm{NO}_{x}$ and $\mathrm{NH}_{3}$ emissions during fertiliser production and consequently contributed to acidification and eutrophication environmental categories [134].

As demonstrated in Fig. 8a for the bioethanol production (scenario 1), the biomass (sugarcane cultivation and bagasse production in the sugar mill) contributed about 65-85\% to abiotic depletion, fossil fuel depletion and ODP impacts, while it delivered 3-35\% of the environmental impacts across all other impact categories due to agrochemical inputs in plantation and diesel consumption as well as emissions released from agricultural lands (i.e. $\mathrm{N}$ leaching). The abiotic depletion is dominated by the fossil fuel oil consumption during the harvesting process and transportation of sugarcane. The combustion unit in scenario 1 not only contributed $83-88 \%$ of the environmental burdens in $\mathrm{GWP}_{100}$, and eco-toxicities impact categories, but also led to $61 \%$ eutrophication impacts because of flue gas emissions $\left(\mathrm{CO}_{2}, \mathrm{CH}_{4}\right.$, $\mathrm{No}_{x}$ ) produced by the biomass combustion. Landfilling of ash from combustion caused $70 \%$ of impacts on human toxicity due to heavy metals such as Antimony released to waterborne bodies [135, 136]. Enzyme production and combustion units were the main contributors to eutrophication impacts (20 and 61\%, respectively) due to waterborne emissions such as phosphate caused by consumption of phosphate fertilisers and diammonium phosphate (for enzyme production). The WWT unit contributed 35\% in acidification and POCP, due to airborne emissions such as $\mathrm{SO}_{2}$. About 10-12\% of the impacts on GWP $_{100}$ and POCP burdens were attributed to flue gas emitted to the atmosphere during bioethanol production and purification, e.g. $\mathrm{N}_{2}, \mathrm{CO}_{2}$ and $\mathrm{SO}_{2}$ released as well as ethanol loss.

Similar to scenario 1, sugarcane cultivation accounting for $20-75 \%$ of the environmental burdens on acidification, ODP, eutrophication and abiotic depletion, was the main cause of environmental issues in scenario 2 (Fig. 8b). The biomass combustion stage contributed to about $35 \%$ of acidification and POCP impacts due to airborne emissions such as $\mathrm{SO}_{2}$ caused by urea consumption. However, lactic acid production was also one of the main contributors to environmental burdens as a consequence of chemical consumption $\left[\mathrm{K}_{2} \mathrm{HPO}_{4}, \mathrm{MgSO}_{4}\right.$, trimethylamine (TEA)]. The LA production process accounted for $5-26 \%$ of abiotic depletion, acidification, human toxicity as well as eutrophication, due to phosphate fertiliser and magnesium sulphate consumption. It contributed to $40 \%$ of POCP, mainly because of the ethanol released to the atmosphere in LA production process.

Considering scenario 3 (Fig. 8c), the furfural production process was the main environmental contributor, accounted for $33-75 \%$ of burdens in POCP, ODP, 
a

$\begin{array}{ll}\text { \Pretreatment } & \square \text { Enzyme production } \\ \text { E ESSCF } & \text { EtOH purification } \\ \text { 圆Evaporation } & \text { Combustion } \\ \square W W T & \text { Biomass production }\end{array}$

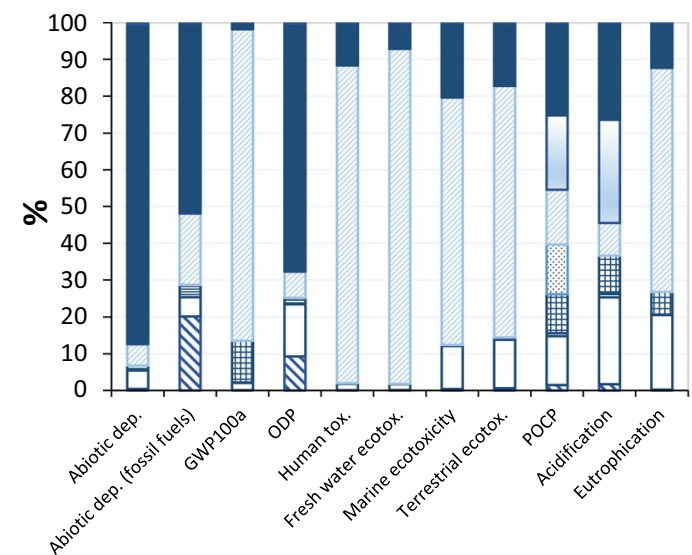

C

$\begin{array}{ll}\Delta \text { Pretreatment } & \square \text { Enzyme production } \\ \text { ESScF } & \text { 田EtOH purification } \\ \text { mEvaporation } & \text { Combustion }\end{array}$

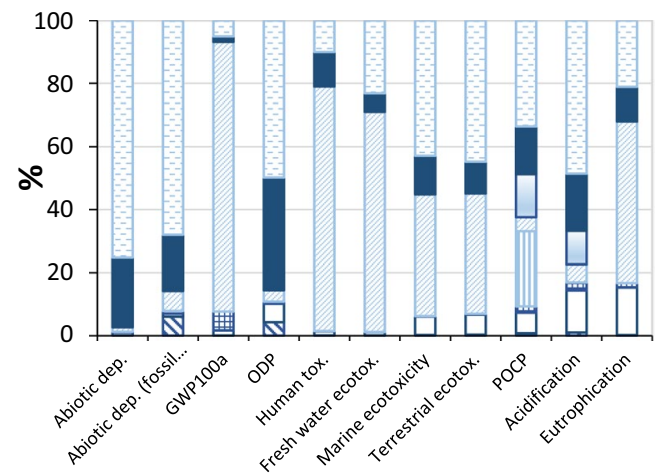

e

$\square$ Combustion $₫$ Gasification and conditioning $\square$ Health check

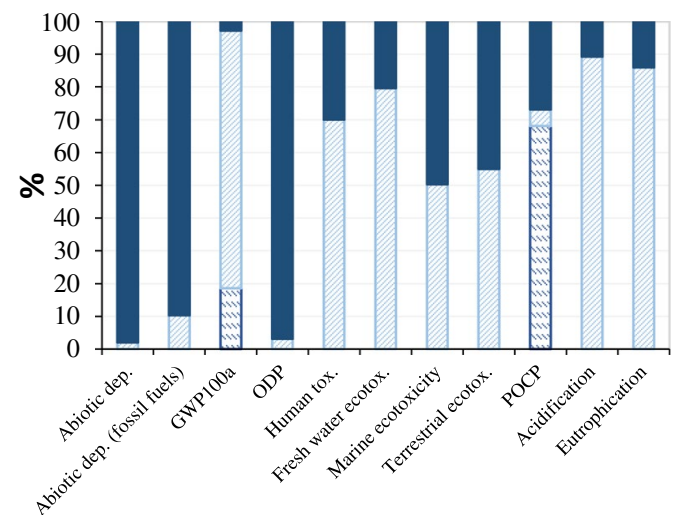

b

Q Pretreatment
目SScF
$\square$ Evaporation
$\square W W T$

$\square$ Enzyme production 国EtOH purification

Combustion

Lactic Acid
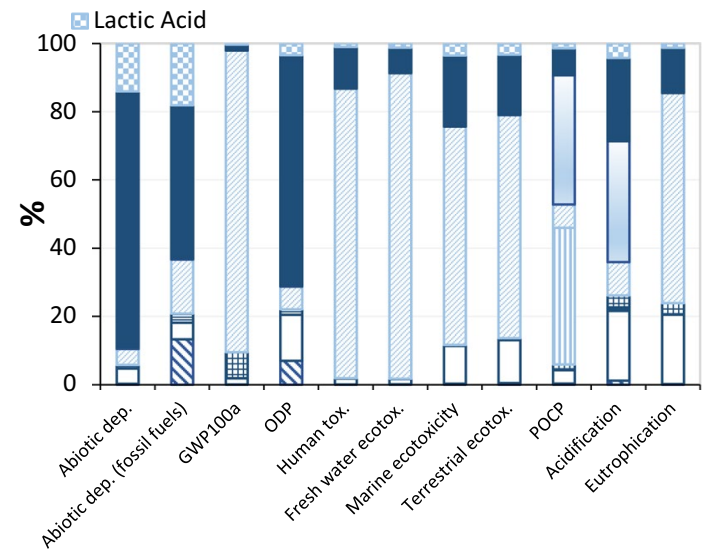

d
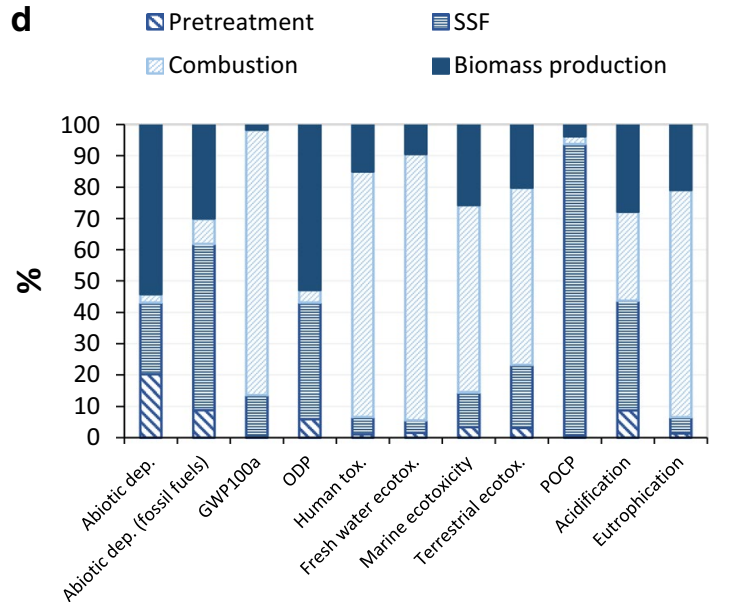

f

国FTS Combustion $₫$ Gasification and conditioning Health check

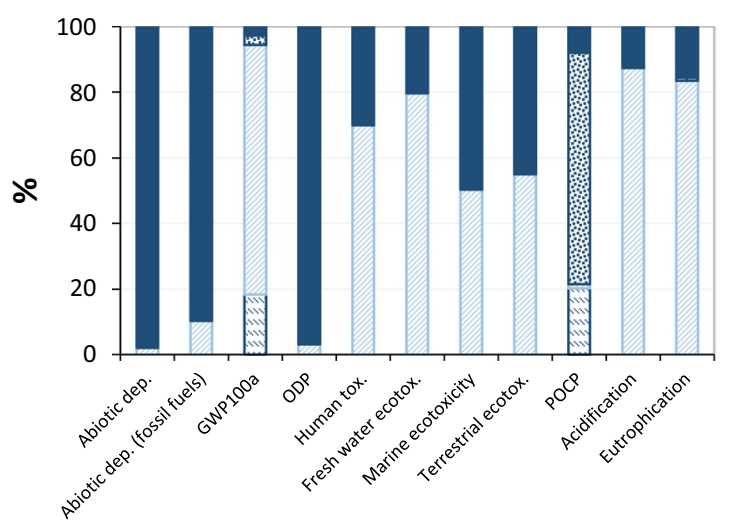

Fig. 8 Characterised LCIA profiles of biorefineries; (unit: 1 tonne of product as defined in the caption; Method CML-IA 2 baseline). a Scenario 1 ethanol; b scenario 2 lactic acid; c scenario 3 furfural; $\mathbf{d}$ scenario 4 butanol; e scenario 5 methanol; $\mathbf{f}$ scenario 6 FT syncrude 


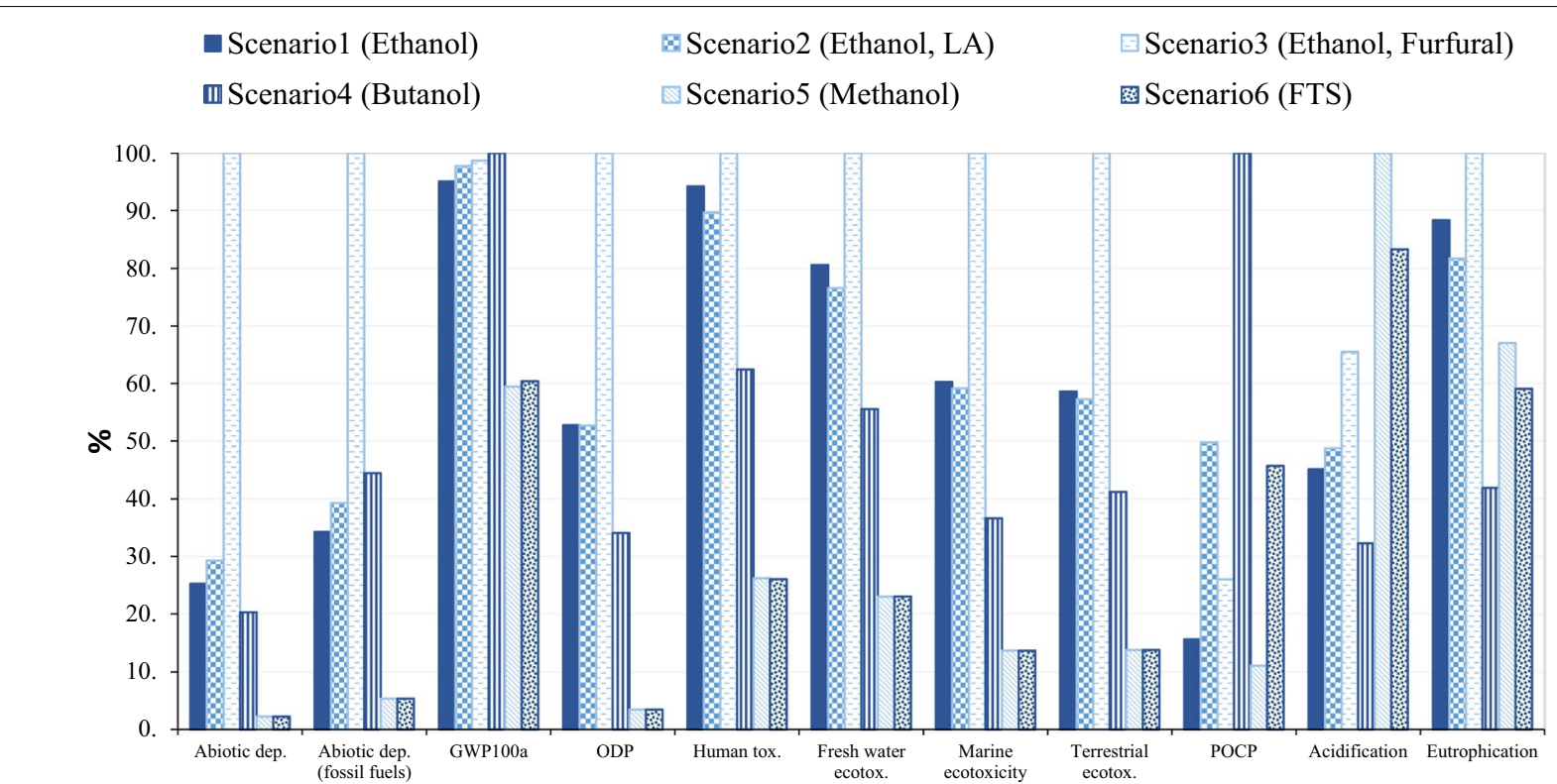

Fig. 9 Characterised LCIA profiles for comparison of biorefinery scenarios (including biogenic C, method: CML-IA baseline 2)

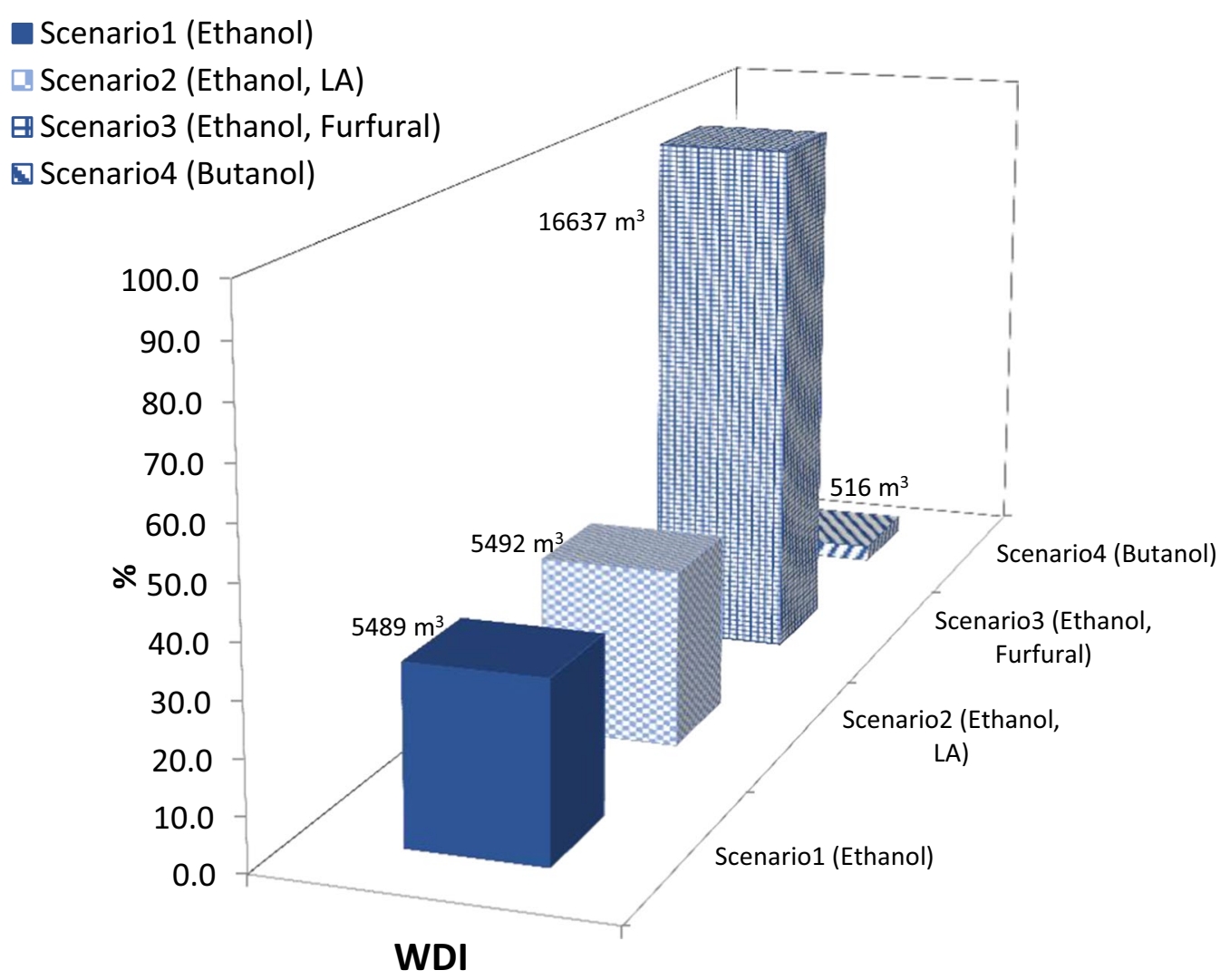

Fig. 10 Water consumption of investigated scenarios per hour 


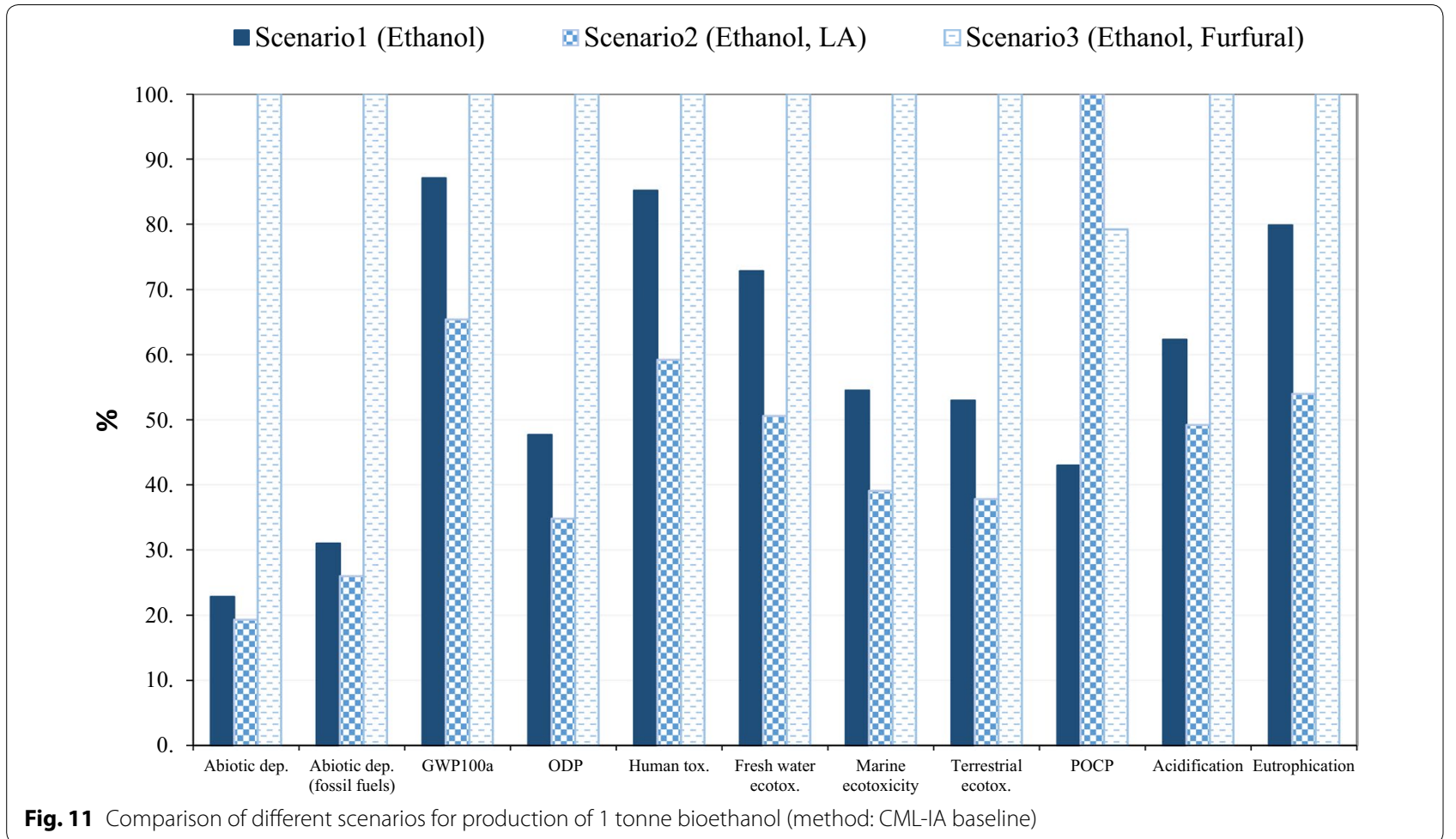

Fig. 11 Comparison of different scenarios for production of 1 tonne bioethanol (method: CML-IA baseline)

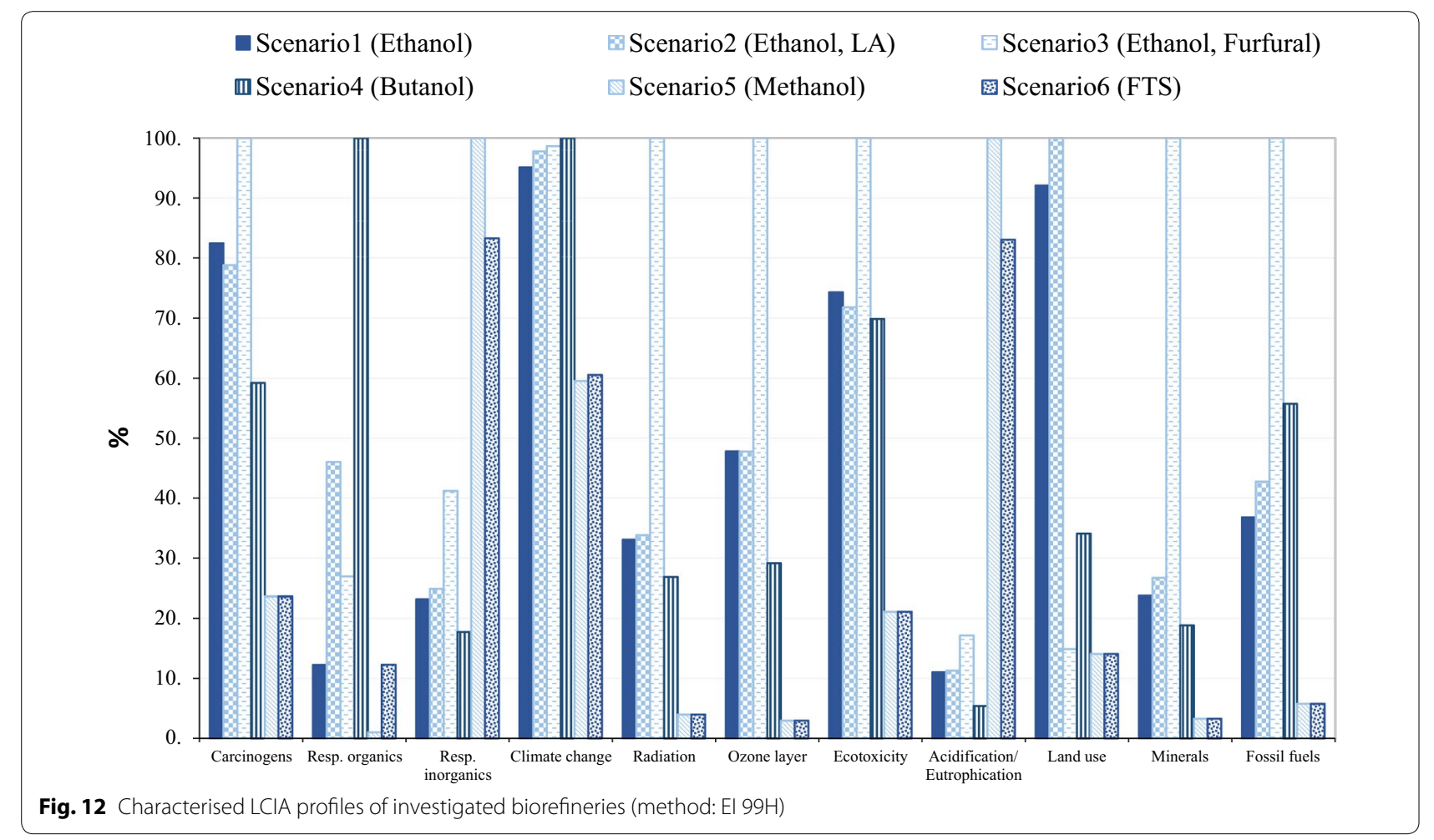


acidification, abiotic depletion (fossil fuel) as well as abiotic depletion due to emissions to air (e.g. $\mathrm{CH}_{4}, \mathrm{C}_{2} \mathrm{H}_{6}$ and $\mathrm{SO}_{2}$ ) and heavy metal released to water (e.g. chromium), as a consequence of $\mathrm{HCl}, \mathrm{NaCl}$ and THF consumption during the process. In eutrophication, furfural production caused $21 \%$ of impacts due to THF and $\mathrm{HCl}$ consumption, whereas the main contributor was biomass combustion (51\%) due to phosphate released to water as a consequence of phosphate fertiliser inputs at the biomass cultivation stage.

As demonstrated in Fig. 8d, the environmental burdens were mainly attributable to sugarcane cultivation, the combustion stage and the SSF unit in scenario 4 . The SSF unit contributed to $30-50 \%$ of total impacts on acidification, ODP and abiotic depletion due to emissions to atmosphere, i.e. nitrogen oxides and methane (as a consequence of urea consumption and transport). This unit showed a significant contribution to POCP burdens (93\%), due to ethanol, butanol and acetone emissions to the atmosphere.

In gasification scenarios (Fig. 8e, f), biomass gasification contributed around $20 \%$ of $\mathrm{GWP}_{100}$ and POCP environmental burdens as a consequence of considerable $\mathrm{CO}_{2}$ and $\mathrm{CO}$ emission during the syngas conditioning process. The combustion stage represented a dominating contributor (range of 50-90\%) to the impacts on GWP (because of $\mathrm{CO}_{2}$ emissions), human toxicity (as a result of heavy metals released to water bodies such as Antimony), acidification and eutrophication (due to the emission of nitrogen oxide to air). The FTS contributed to less than $5 \%$ of GWP ${ }_{100}$ burdens and over 70\% POCP impacts as a result of $\mathrm{CH}_{4}, \mathrm{CO}$ and butane release to the atmosphere.

Previous studies indicated that a $10 \%$ increase in the biomass output and its availability (per unit land area) for biorefinery processing incurred more $\mathrm{CO}_{2}$ savings than a $10 \%$ increase in the yield of the bio-conversion methods [30]. This is consistent with our research finding from the contribution analyses above, which suggested that improvements in agrochemical utilisation efficiency in agricultural practice (e.g. lower fertiliser inputs per unit biomass harvested) would lead to overall environmental savings particularly on abiotic depletion and ODP. In addition, further research efforts should be placed on the chemical reduction in biochemical routes and the effective emission abatement technology and ash disposal at combustion stage.

\section{LCA comparison}

In order to identify the sustainable scenarios for utilisation of biomass, the LCIA of the investigated biorefinery pathways based on the conversion of a functional unit of feedstock ( $65 \mathrm{tDM} / \mathrm{h})$ has been compared as presented in Fig. 9.
The results for LCIA comparisons varied with impact categories. Overall, the gasification scenarios (thermochemical pathway) benefitted from their lower chemical inputs and energy demands; therefore, they presented environmental advantages over biochemical pathways on most of the categories, except for acidification and eutrophication. Indirect emissions associated with process chemical consumption have been reported as the hot spot of the biochemical pathway, while the thermochemical route has been determined to have lower GHG emissions in previous studies [121, 137, 138]. However, our gasification scenarios incurred some higher burdens, for example, due to acidification due to the $\mathrm{NO}_{x}$ released from the combustion of biomass.

The gasification scenarios showed broadly similar environmental performances in most of the impact categories, because syngas production and conditioning processes did not vary with scenarios. However, scenario 5 represented slightly higher acidification and eutrophication impacts than scenario 6, as a consequence of the higher bypass (35\% in scenario 5 vs. $30 \%$ in scenario 6 ) of the feedstock to the CHP. On the other hand, scenario 6 had a three-time higher POCP environmental burden than scenario 5, due to emissions from the FTS process, i.e. methane and butane emissions which do not occur in methanol production process.

Comparing the biochemical pathways, butanol delivered a better performance than other routes in most of the categories because of lower chemical inputs, while it suffers from higher POCP impacts compared with other scenarios, due to the ethanol and acetone emissions released from the distillate stage. The co-production of ethanol and furfural (scenario 3) presented the worst biochemical scenario on most of the environmental impact categories. This can be explained by the highest feedstock bypass in scenario 3, which resulted in significantly higher GHGs and eutrophication emissions, as well as high consumption of chemicals (such as THF, $\mathrm{HCl}$ and $\mathrm{NaCl}$ ) leading to higher environmental burdens in the ODP, abiotic depletion and acidification impact categories. Scenarios 1 and 2 represented similar environmental outcomes in abiotic depletion, acidification, $\mathrm{GWP}_{100}$ and ODP, while scenario 2 incurred higher POCP and acidification burdens than scenario 1 . That can be ascribed to the slightly lower bypass in scenario 1 (35 via 40\%) and higher chemical inputs in LA process $\left(\mathrm{K}_{2} \mathrm{HPO}_{4}\right.$ and TEA).

Water use is categorised into required water for the processes, while sugarcane cultivation in South Africa is mostly non-irrigated. As reflected in Fig. 10, furfural production (scenario 3) has the highest water consumption profiles, which was mainly driven by the waste water treatment section. 
The environmental burdens of the three scenarios producing ethanol (scenario 1-3) were compared to identify the most sustainable pathway to produce bioethanol (Fig. 11). The results implied that scenario 2 delivered the best environmental performance in almost all the impact categories, except for POCP, where additional ethanol emissions during the LA production process (consuming ethanol) in scenario 2 resulted in a higher POCP burden than the other two scenarios. Scenario 1 produced a greater amount of unconverted residue than scenario 2 , which is sent for combustion in CHP unit, and thus resulted in a less favourable option for bioethanol production than scenario 2 , whereas scenario 3 is presented as the least sustainable bioethanol production system due to the consumption of chemicals such as THF and $\mathrm{HCl}$ in furfural production.

\section{Sensitivity analysis on characterisation model and allocation approach}

As an alternative to the midpoint method CML-IA baseline, the damage-oriented method Eco-Indicator $99 \mathrm{H}$ (hierarchist, version 2.10) was applied to the LCA model. Although the impact categories evaluated in the two methods are not identical, most of them overlapped. The CML-IA baseline represents eco-toxicity in three sub-categories, while Eco-Indicator $99 \mathrm{H}$ shows only an aggregated eco-toxic indicator result. As an equivalent to photochemical oxidation in CML-IA baseline (summer smog), Eco-indicator 99 includes a respiratory organics impact category where respiratory effects resulting from exposure to organic compounds in summer smog are evaluated [139, 140]. Eco-indictor 99 also accounts for winter smog (respiratory inorganic), damages induced by radioactive radiation and conversion and occupation of land [139] all of which are not in the scope of CML baseline method. Unlike the CML method, EI 99 aggregates acidification and eutrophication potential of all substances into a single indicator result. Abiotic depletion in CML accounts for the aggregated mineral resources, which is equivalent to the mineral impact category under EI99 method, whereas both CML fossil abiotic depletion and EI99 fossil fuel impact categories focus on fossil fuel resources only.

As demonstrated in Fig. 12, the gasification scenarios appear to deliver the highest impact in the aggregated acidification/eutrophication EI 99 category, while according to the CML findings, the gasification scenarios incurred higher acidification, but lower eutrophication scores compared to biochemical scenarios. The results of EI 99 broadly agreed with CML method in abiotic depletion, fossil fuel depletion, $\mathrm{GWP}_{100}$, eco-toxicity, POCP and ODP impact categories.

\section{Socio-economic impacts and overall sustainability assessment}

Regardless of the emphasis placed on environmental aspects of biofuel, many authors have agreed on the key role of socio-economic motivations in the rise of biofuel markets. Biorefineries can provide significant job creation, mostly in the supply of feedstock to the sugar mill, i.e. the harvesting residues. The so-called "green cane harvesting" as an alternative to burning cane before harvesting would essentially double the number of jobs in harvesting, while also creating additional jobs in collection and transport of residues to the sugar mills. Based on the available data on South African and Brazilian agriculture $[18,140]$, the created job for manual trash collection from the field, baling the material and transportation was estimated as $0.205 \mathrm{t} / \mathrm{man}-\mathrm{h}$. All the scenarios were assessed processing the same amount of feedstock $(145,800 \mathrm{t} /$ year $)$; therefore, the number of created jobs for green harvesting, collection and transformation was estimated as 89,000 man-day/year for all the scenarios $[141,142]$. The number of jobs created at the process stage was estimated based on the complexity of the processes as $48,60,60,40,43$ and 39 , respectively, for the evaluated scenarios (1-6). Due to high levels of automation applied in processing plants, the number of skilled jobs created, including plant manager, engineers, supervisors, operators and administrative jobs, was limited [143].

A normalised spider chart has been introduced in this study to illustrate the different pathways with eight indicators, i.e. IRR, job creation, eutrophication, $\mathrm{GWP}_{100}$, ODP, POCP, acidification and abiotic depletion. The route with the largest occupied area represents the inferior system. The results of the sustainability assessment (Fig. 13) imply that scenario 5 outperformed the other case studies, benefitting from its environmentally superior profile. The scenario 2 (lactic acid production) delivered the highest IRR, better socio-economic sustainability and a lower GWP ${ }_{100}$ score than other biochemical routes, based on its IRR and job creation potential. Furfural production (scenario 3) appeared as the least economically competitive and environmentally friendly option in comparison with other routes, although it exhibits good job creation potential. To achieve better sustainability scores in scenario 3 , research and development attention should be placed on minimising the solvent consumption (or increasing solvent internal recycling) and improving the furfural productivity. Our research also suggested a range of bottlenecks for further improvement of the overall performance in the scenarios with biphasic production systems particularly achieving the trade-offs between environmental sustainability and 


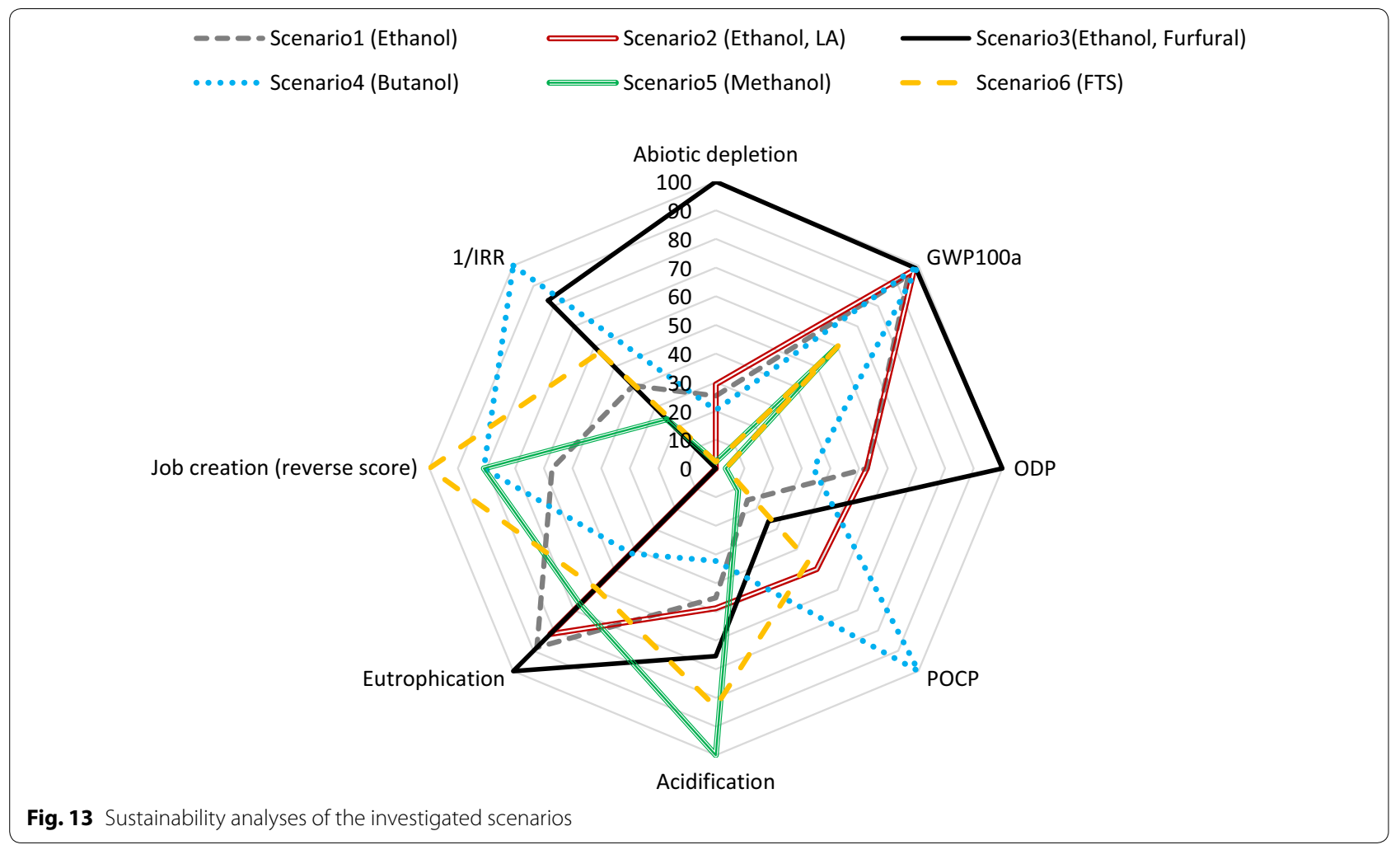

economic viability, i.e. solvent recycling which has potential for reduction in environmental damages and solvent costs but may incur additional operational costs.

\section{Conclusions}

Detailed modelling, simulations and analyses of six scenarios have been developed to gain a better understanding of the potential for product diversification in the sugarcane industry by means of biorefineries. All the biorefinery scenarios were designed on the basis of being self-sufficient in bioenergy, thus rerouting a portion of the total lignocellulose feedstock directly to the boiler (CHP plant), rather than supplementing bioenergy sources with fossil fuels such as coal or natural gas. Economic evaluation of the scenarios implied that scenarios 2 (ethanol, LA) and 5 (methanol) had the highest profitability, while the former was the most robust scenario considering product price fluctuation, benefiting from multi-product revenues. LCA modelling has demonstrated that biomass cultivation played an important role in the environmental burden which demonstrated the importance of sustainable agricultural management on bio-based chemical production. Furfural production through a biphasic process contributed significantly to the environmental burdens (in all impact categories), which revealed the necessity of investigating other technologies to improve the yield of furfural, while avoiding solvent consumption. Gasification scenarios offered substantial environmental benefits over biochemical pathways due to lower levels of chemical consumption. Sustainable development of sugar industry could be moved forward by annexing $2 \mathrm{G}$ biorefinery into existing sugar mill to utilise lignocellulosic residues for production of some specific biofuels/biochemicals.

\section{Additional file}

Additional file 1: Table S1. The main parameters implemented for the Aspen simulation of biorefinery scenarios. Table S2. Utilities condition of the developed biorefinery scenarios. Table S3. The specific energy consumption of the studied biorefinery scenarios (data of Fig. 4). Table S4. The detailed sales of the studied scenarios (data of Fig. 6). Table S5. Inventory for sugarcane cultivation. Table S6. Inventory for sugarcane processing in the sugar mill. Table S7. Inventory for the investigated biorefinery scenarios (per 65 ton/h biomass processed). Table S8. LCIA profiles of bioethanol production (unit: 1 ton bioethanol; method: CML-IA baseline V3.02). Table S9. LCIA profiles of bioethanol and lactic acid production (unit: 1 ton Lactic acid; method: CML-IA baseline V3.02). Table S10. LCIA profiles of bioethanol and furfural production (unit: 1 ton Furfural; method: CML-IA baseline V3.02). Table S11. LCIA profiles of butanol production (unit: 1 ton butanol; method: CML-IA baseline V3.02). Table S12. LCIA profiles of methanol production (unit: 1 ton methanol; method: CML-IA baseline V3.02). Table S13. LCIA profiles of FT syncrude production (unit: 1 ton FT syncrude; method: CML-IA baseline V3.02). Table S14. LCIA profiles for comparison of biorefinery scenarios (method: CML-IA baseline V3.02). Table S15. LCIA profiles for comparison of different scenarios for production of 1 tonne bioethanol (method: CML-IA baseline V3.02). Table S16. LCIA profiles for comparison of biorefinery scenarios (method: El 99H). Figure S1. A schematic diagram of carbon flows through a biorefinery scenario (from sugarcane to final products. 


\section{Abbreviations}

ABE: acetone-butanol-ethanol; aLCA: attributional life cycle assessment; ALOG: allothermal gasification; BRICS: Brazil, Russia, India and China; CHP: combined heat and power; CML: Centre of Environmental Science; DM: dry matter; EtOH: ethanol; EU: European Union; FT: Fischer-Tropsch; GHG: greenhouse gas; $\mathrm{GWP}_{100}$ : global warming potential; IRR: internal rate of return; LA: lactic acid; LCA: life cycle assessment; LCIA: life cycle impact assessment; LCl: life cycle inventory; ODP: ozone depletion; OPEX: operating costs; POCP: photochemical oxidation; $\mathrm{R}_{3} \mathrm{~N}$ : trimethylamine; $\mathrm{SA}$ : South Africa; SScF: simultaneous saccharification and co-fermentation; SSF: saccharification and fermentation; $\mathrm{TCl}$ : total capital investment; THF: tetrahydrofuran; USA: United States of America; WWT: waste water treatment; 1G2G: integrated of first and second generation; 2G: second generation.

\section{Authors' contributions}

SF has developed the simulation of methanol, FTS and CHP units, performed the LCA analysis of the whole scenarios and writing up the relevant sections. MAM has developed the simulations for $\mathrm{EtOH}, \mathrm{EtOH}-\mathrm{LA}$, butanol and $\mathrm{EtOH}$ furfural scenarios and accomplished the economic evaluation of the whole studied scenarios along with writing up the relevant sections. MG has guided LCA analysis and simulation of scenarios in SimaPro, reviewed the results and contributed strongly in the manuscript write up. KFH has developed the process of furfural production from hemicellulose. NS has participated in proof reading of the manuscript. JFG conceived the study, participated in its design coordination and reviewed the manuscript. All authors read and approved the final manuscript.

\section{Author details}

${ }^{1}$ Department of Process Engineering, Stellenbosch University, Stellenbosch 7600, South Africa. ${ }^{2}$ Department of Chemical Engineering, Imperial College London, London SW7 2AZ, UK.

\section{Acknowledgements}

We would like to acknowledge Aspen Technology Inc., since this work was carried out using their registered trademark "Aspen Plus ${ }^{\circledR}$." We are grateful to Royal Society Newton International Exchange for funding travel costs and to National Research Foundation (NRF) for the bursary of Kathleen Haigh. Opinions expressed and conclusions arrived at are those of the authors and are not necessarily to be attributed to the Green Fund, DBSA, DEA, Royal Society or NRF.

\section{Competing interests}

The authors declare that they have no competing interests.

\section{Availability of data and materials}

All data generated or analysed during this study are included in this published article and its additional files.

\section{Consent for publication}

All authors agree to publication.

\section{Funding}

This study is based on research financially supported by the Green Fund, an environmental finance mechanism implemented by the Development Bank of Southern Africa (DBSA) on behalf of the Department of Environmental Affairs (DEA)

Received: 6 October 2016 Accepted: 18 March 2017

Published online: 11 April 2017

\section{References}

1. Clauser NM, Gutiérrez S, Area MC, Felissia FE, Vallejos ME. Small-sized biorefineries as strategy to add value to sugarcane bagasse. Chem Eng Res Des. 2016;107:137-46.

2. Mabee WE, Saddler JN. Bioethanol from lignocellulosics: status and perspectives in Canada. Bioresour Technol. 2010;101:4806-13.

3. Tao L, Tan ECD, McCormick R, Zhang M, Aden A, He X, Zigler BT. Technoeconomic analysis and life-cycle assessment of cellulosic isobutanol and comparison with cellulosic ethanol and $n$-butanol. Biofuels Bioprod Biorefin. 2014;8:30-48.

4. Chum HL, Warner E, Seabra JEA, Macedo IC. A comparison of commercial ethanol production systems from Brazilian sugarcane and US corn. Biofuels Bioprod Biorefin. 2014;8:205-23.

5. Eggert H, Greaker M. Promoting second generation biofuels: does the first generation pave the road? Energies. 2014;7:4430-45.

6. Mofijur M, Masjuki HH, Kalam MA, Ashrafur Rahman SM, Mahmudul HM. Energy scenario and biofuel policies and targets in ASEAN countries. Renew Sustain Energy Rev. 2015;46:51-61.

7. Van Zyl W, Prior BA. South Africa biofuels. IEA Task Group. 2009;39:1-5.

8. de Jong E, Higson A, Walsh P, Wellisch M. Product developments in the bio-based chemicals arena. Biofuels Bioprod Biorefin. 2012;6:606-24.

9. Bos HL, Sanders JPM. Raw material demand and sourcing options for the development of a bio-based chemical industry in Europe. Biofuels Bioprod Biorefin. 2013;7:246-59.

10. Isikgor FH, Becer CR. Lignocellulosic biomass: a sustainable platform for the production of bio-based chemicals and polymers. Polym Chem. 2015;6:4497-559.

11. Quintero JA, Moncada J, Cardona CA. Techno-economic analysis of bioethanol production from lignocellulosic residues in Colombia: a process simulation approach. Bioresour Technol. 2013;139:300-7.

12. Moncada J, Cardona CA, Higuita JC, Vélez JJ, López-Suarez FE. Wood residue (Pinus patula bark) as an alternative feedstock for producing ethanol and furfural in Colombia: experimental, techno-economic and environmental assessments. Chem Eng Sci. 2016;140:309-18.

13. Haro P, Villanueva Perales ÁL, Arjona R, Ollero P. Thermochemical biorefineries with multiproduction using a platform chemical. Biofuels Bioprod Biorefin. 2014;8:155-70.

14. Bezerra TL, Ragauskas AJ. A review of sugarcane bagasse for secondgeneration bioethanol and biopower production. Biofuels Bioprod Biorefin. 2016;10:634-47.

15. Bensah EC, Kemausuor F, Miezah K, Kádár Z, Mensah M. African perspective on cellulosic ethanol production. Renew Sustain Energy Rev. 2015:49:1-11.

16. Reid M: Why do we continue to burn so much coal. In: Proc S Afr Sug Technol Ass. 2006. p. 353-63.

17. Cherubini F. The biorefinery concept: using biomass instead of oil for producing energy and chemicals. Energy Convers Manag. 2010:51:1412-21.

18. Smithers J. Review of sugarcane trash recovery systems for energy cogeneration in South Africa. Renew Sustain Energy Rev. 2014;32:915-25

19. Balat M. Global bio-fuel processing and production trends. Energy Explor Exploit. 2007;25:195-218.

20. Vanholme B, Desmet T, Ronsse F, Rabaey K, Van Breusegem F, De Mey M, Soetaert W, Boerjan W. Towards a carbon-negative sustainable biobased economy. Front Plant Sci. 2013;4:174.

21. Hosseini SA, Lambert R, Kucherenko S, Shah N. Multiscale modeling of hydrothermal pretreatment: from hemicellulose hydrolysis to biomass size optimization. Energy Fuels. 2010;24:4673-80.

22. Kazi FK, Fortman JA, Anex RP, Hsu DD, Aden A, Dutta A, Kothandaraman G. Techno-economic comparison of process technologies for biochemical ethanol production from corn stover. Fuel. 2010;89:S20-8.

23. Gassner M, Maréchal F. Methodology for the optimal thermo-economic, multi-objective design of thermochemical fuel production from biomass. Comput Chem Eng. 2009:33:769-81.

24. Haarlemmer G, Boissonnet G, Imbach J, Setier P-A, Peduzzi E. Second generation BtL type biofuels - a production cost analysis. Energy Environ Sci. 2012;5:8445.

25. Kim K, Kim Y, Yang C, Moon J, Kim B, Lee J, Lee U, Lee S, Kim J, Eom W, et al. Long-term operation of biomass-to-liquid systems coupled to gasification and Fischer-Tropsch processes for biofuel production. Bioresour Technol. 2013;127:391-9.

26. Alonso DM, Bond JQ, Dumesic JA. Catalytic conversion of biomass to biofuels. Green Chem. 2010;12:1493-513.

27. Sheldon RA. Green and sustainable manufacture of chemicals from biomass: state of the art. Green Chem. 2014;16:950-63.

28. Gallezot P. Conversion of biomass to selected chemical products. Chem Soc Rev. 2012:41:1538-58. 
29. Bozell JJ, Petersen GR. Technology development for the production of biobased products from biorefinery carbohydrates - the US Department of Energy's "Top 10" revisited. Green Chem. 2010;12:539.

30. Khoo HH, Ee WL, Isoni V. Bio-chemicals from lignocellulose feedstock: sustainability, LCA and the green conundrum. Green Chem. 2016;18:1912-22.

31. ISO I. 14040: Environmental management—life cycle assessmentprinciples and framework. London: British Standards Institution; 2006.

32. Renó MLG, del Olmo OA, Palacio JCE, Lora EES, Venturini OJ. Sugarcane biorefineries: Case studies applied to the Brazilian sugar-alcohol industry. Energy Convers Manag. 2014;86:981-91.

33. Cavalett O, Chagas MF, Seabra JEA, Bonomi A. Comparative LCA of ethanol versus gasoline in Brazil using different LCIA methods. Int J Life Cycle Assess. 2013;18:647-58.

34. Papong S, Malakul P. Life-cycle energy and environmental analysis of bioethanol production from cassava in Thailand. Bioresour Technol. 2010;101:S112-8.

35. Guo M, Littlewood J, Joyce J, Murphy R. The environmental profile of bioethanol produced from current and potential future poplar feedstocks in the EU. Green Chem. 2014;16:4680-95.

36. Luque R, Lovett JC, Datta B, Clancy J, Campelo JM, Romero AA. Biodiesel as feasible petrol fuel replacement: a multidisciplinary overview. Energy Environ Sci. 2010;3:1706-21.

37. Smith G, Davis S, Madho S, Achary M. Ninetieth annual review of the milling season in southern Africa (2014/15). In: Proceedings of the annual congress-South African Sugar Technologists' Association. South African Sugar Technologists' Association; 2015. p. 23-54.

38. Olivier FC, Singels A. The effect of crop residue layers on evapotranspiration, growth and yield of irrigated sugarcane. Water SA. 2012;38:77-86.

39. Seabra JEA, Tao L, Chum HL, Macedo IC. A techno-economic evaluation of the effects of centralized cellulosic ethanol and co-products refinery options with sugarcane mill clustering. Biomass Bioenergy. 2010;34:1065-78.

40. Petersen AM, Aneke MC, Görgens JF. Techno-economic comparison of ethanol and electricity coproduction schemes from sugarcane residues at existing sugar mills in Southern Africa. Biotechnol Biofuels. 2014;7:105.

41. Dias MO, Junqueira $T L$, Cavalett $O$, Cunha MP, Jesus $C D$, Rossell $C E$, Maciel Filho R, Bonomi A. Integrated versus stand-alone second generation ethanol production from sugarcane bagasse and trash. Bioresour Technol. 2012;103:152-61.

42. Benjamin Y, Cheng H, Görgens JF. Evaluation of bagasse from different varieties of sugarcane by dilute acid pretreatment and enzymatic hydrolysis. Ind Crops Prod. 2013;51:7-18.

43. Consonni S, Katofsky RE, Larson ED. A gasification-based biorefinery for the pulp and paper industry. Chem Eng Res Des. 2009;87:1293-317.

44. Fatih Demirbas M. Biorefineries for biofuel upgrading: a critical review. Appl Energy. 2009;86:S151-61.

45. Kuglarz M, Alvarado-Morales M, Karakashev D, Angelidaki I. Integrated production of cellulosic bioethanol and succinic acid from industrial hemp in a biorefinery concept. Bioresour Technol. 2016;200:639-47.

46. Karlsson H, Börjesson P, Hansson P-A, Ahlgren S. Ethanol production in biorefineries using lignocellulosic feedstock-GHG performance, energy balance and implications of life cycle calculation methodology. J Clean Prod. 2014;83:420-7.

47. Pereira LG, Dias MOS, Junqueira TL, Pavanello LG, Chagas MF, Cavalett O, Maciel Filho R, Bonomi A. Butanol production in a sugarcane biorefinery using ethanol as feedstock. Part Il: integration to a second generation sugarcane distillery. Chem Eng Res Des. 2014;92:1452-62.

48. Cai CM, Zhang T, Kumar R, Wyman CE. Integrated furfural production as a renewable fuel and chemical platform from lignocellulosic biomass. J Chem Technol Biotechnol. 2014:89:2-10.

49. Abdel-Rahman MA, Tashiro Y, Sonomoto K. Recent advances in lactic acid production by microbial fermentation processes. Biotechnol Adv. 2013;31:877-902.

50. Dusselier M, Van Wouwe P, Dewaele A, Makshina E, Sels BF. Lactic acid as a platform chemical in the biobased economy: the role of chemocatalysis. Energy Environ Sci. 2013;6:1415.

51. Maki-Arvela P, Simakova IL, Salmi T, Murzin DY. Production of lactic acid/ lactates from biomass and their catalytic transformations to commodities. Chem Rev. 2014;114:1909-71.
52. Taylor R, Nattrass L, Alberts G, Robson P, Chudziak C, Bauen A, Libelli I, Lotti G, Prussi M, Nistri R. From the sugar platform to biofuels and biochemicals: final report for the European Commission DirectorateGeneral Energy. E4tech/Re-CORD/Wageningen UR; 2015.

53. Ali Mandegari M, Farzad S. Görgens JF. In: Singh RS, Panday A, Gnansounou E, editors. Biofuels: production and future perspectives. Boca Raton: CRC Press; 2016.

54. Brugnago RJ, Satyanarayana KG, Wypych F, Ramos LP. The effect of steam explosion on the production of sugarcane bagasse/polyester composites. Compos Part A Appl Sci Manuf. 2011;42:364-70.

55. Oliveira FM, Pinheiro IO, Souto-Maior AM, Martin C, Goncalves AR, Rocha GJ. Industrial-scale steam explosion pretreatment of sugarcane straw for enzymatic hydrolysis of cellulose for production of second generation ethanol and value-added products. Bioresour Technol. 2013;130:168-73.

56. Martín C, Galbe M, Nilvebrant N-O, Jönsson LJ. Comparison of the fermentability of enzymatic hydrolyzates of sugarcane bagasse pretreated by steam explosion using different impregnating agents. Appl Biochem Biotechnol. 2002;98:699-716.

57. Ali Mandegari M, Farzad S, Görgens JF. Economic and environmental assessment of cellulosic ethanol production scenarios annexed to a typical sugar mill. Bioresour Technol. 2017;224:314-26.

58. Karimi K, Chisti Y. Future of bioethanol. Biofuel Res J. 2015;2:147.

59. Humbird D, Davis R, Tao L, Kinchin C, Hsu D, Aden A, Schoen P, Lukas J, Olthof B, Worley $\mathrm{M}$, et al. Process design and economics for biochemical conversion of lignocellulosic biomass to ethanol. Technical Report NREL/TP-5100-47764. Golden: National Renewable Energy Laboratory; 2011.

60. Batista FRM, Follegatti-Romero LA, Bessa LCBA, Meirelles AJA. Computational simulation applied to the investigation of industrial plants for bioethanol distillation. Comput Chem Eng. 2012;46:1-16.

61. Dias MO, Cunha MP, Jesus CD, Rocha GJ, Pradella JG, Rossell CE, Filho RM, Bonomi A. Second generation ethanol in Brazil: can it compete with electricity production? Bioresour Technol. 2011;102:8964-71.

62. Errico M, Rong B-G, Tola G, Spano M. Optimal synthesis of distillation systems for bioethanol separation. Part 2. Extractive distillation with complex columns. Ind Eng Chem Res. 2013;52:1620-6.

63. Farzad S, Taghikhani V, Ghotbi C, Aminshahidi B, Lay EN. Experimental and theoretical study of the effect of moisture on methane adsorption and desorption by activated carbon at 273.5 K. J Nat Gas Chem. 2007;16:22-30.

64. Montague L, Slayton A, Lukas J. Lignocellulosic biomass to ethanol process design and economics utilizing co-current dilute acid prehydrolysis and enzymatic hydrolysis for corn stover. NREL/TP-510-32438. Colorado: National Renewable Energy Laboratory.

65. Bai Y, Luo L, van der Voet E. Life cycle assessment of switchgrass-derived ethanol as transport fuel. Int J Life Cycle Assess. 2010;15(5):468-77.

66. Ballesteros M, Oliva J, Manzanares P, Negro MJ, Ballesteros I. Ethanol production from paper material using a simultaneous saccharification and fermentation system in a fed-batch basis. World J Microbiol Biotechnol 2002;18:559-61.

67. Taherzadeh MJ, Karimi K. Pretreatment of lignocellulosic wastes to improve ethanol and biogas production: a review. Int J Mol Sci. 2008:9:1621-51.

68. Van Krieken J. Method for preparing an organic amine_-lactic acid complex. Google Patents; 2011.

69. Mandegari MA, Farzad S, van Rensburg E, Görgens JF. Multi criteria analysis of a biorefinery for co- production of lactic acid and ethanol from sugarcane lignocellulose. Energy Environ Sci. 2017 (Under review).

70. Edreder E, Mujtaba I, Emtir M. Optimal operation of different types of batch reactive distillation columns used for hydrolysis of methyl lactate to lactic acid. Chem Eng J. 2011;172:467-75.

71. Su C-Y, YU C-C, Chien I-L, Ward JD. Plant-wide economic comparison of lactic acid recovery processes by reactive distillation with different alcohols. Ind Eng Chem Res. 2013;52:11070-83.

72. Kumar R, Nanavati H, Noronha SB, Mahajani SM. A continuous process for the recovery of lactic acid by reactive distillation. J Chem Technol Biotechnol. 2006:81:1767-77.

73. Xing R, Qi W, Huber GW. Production of furfural and carboxylic acids from waste aqueous hemicellulose solutions from the pulp and paper and cellulosic ethanol industries. Energy Environ Sci. 2011;4:2193. 
74. Zeitsch KJ. The chemistry and technology of furfural and its many byproducts. Amsterdam: Elsevier; 2000.

75. De Jong W, Marcotullio G. Overview of biorefineries based on coproduction of furfural, existing concepts and novel developments. Int J Chem React Eng. 2010;8. doi:10.2202/1542-6580.2174.

76. Karimi K, Pandey A. Current and future ABE processes. Biofuel Res J. 2014;1:77.

77. Karimi K, Tabatabaei M, Sárvári Horváth I, Kumar R. Recent trends in acetone, butanol, and ethanol (ABE) production. Biofuel Res J. 2015;2:301-8

78. Durre P. Fermentative butanol production: bulk chemical and biofuel. Ann N Y Acad Sci. 2008;1125:353-62

79. García A, Alriols MG, Llano-Ponte R, Labidi J. Energy and economic assessment of soda and organosolv biorefinery processes. Biomass Bioenergy. 2011;35:516-25.

80. Qureshi N, Saha BC, Dien B, Hector RE, Cotta MA. Production of butanol (a biofuel) from agricultural residues: part I—use of barley straw hydrolysate. Biomass Bioenergy. 2010;34:559-65.

81. Qureshi N, Saha BC, Hector RE, Dien B, Hughes S, Liu S, Iten L, Bowman MJ, Sarath G, Cotta MA. Production of butanol (a biofuel) from agricultural residues: part II—use of corn stover and switchgrass hydrolysates. Biomass Bioenergy. 2010;34:566-71.

82. Qureshi N, Cotta M, Saha B. Bioconversion of barley straw and corn stover to butanol (a biofuel) in integrated fermentation and simultaneous product recovery bioreactors. Food Bioprod Process. 2014;92:298-308

83. Ezeji TC, Karcher PM, Qureshi N, Blaschek HP. Improving performance of a gas stripping-based recovery system to remove butanol from Clostridium beijerinckii fermentation. Bioprocess Biosyst Eng. 2005;27:207-14.

84. Cai D, Chen H, Chen C, Hu S, Wang Y, Chang Z, Miao Q, Qin P, Wang Z, Wang J, Tan T. Gas stripping-pervaporation hybrid process for energy-saving product recovery from acetone-butanol-ethanol (ABE) fermentation broth. Chem Eng J. 2016;287:1-10.

85. Petersen AM, Farzad S, Gorgens JF. Techno-economic assessment of integrating methanol or Fischer-Tropsch synthesis in a South African sugar mill. Bioresour Technol. 2015;183:141-52.

86. Pfeifer $\mathrm{C}$, Rauch R, Hofbauer H. In-bed catalytic tar reduction in a dual fluidized bed biomass steam gasifier. Ind Eng Chem Res. 2004:43:1634-40.

87. Baratieri M, Baggio P, Fiori L, Grigiante M. Biomass as an energy source: thermodynamic constraints on the performance of the conversion process. Bioresour Technol. 2008;99:7063-73.

88. Farzad S, Mandegari MA, Görgens JF. A critical review on biomass gasification, co-gasification, and their environmental assessments. Biofuel Res J. 2016:3:483-95.

89. Diederichs GW, Ali Mandegari M, Farzad S, Gorgens JF. Technoeconomic comparison of biojet fuel production from lignocellulose, vegetable oil and sugar cane juice. Bioresour Technol. 2016;216:331-9.

90. Sun L, Smith R. Rectisol wash process simulation and analysis. J Clean Prod. 2013:39:321-8.

91. Kumar S. Hydrothermal processing of biomass for biofuels. Biofuel Res J. 2014;1:43

92. Hamelinck CN, Hooijdonk GV, Faaij APC. Ethanol from lignocellulosic biomass: techno-economic performance in short-, middle- and longterm. Biomass Bioenergy. 2005;28:384-410.

93. Phillips SD, Tarud JK, Biddy MJ, Dutta A. Gasoline from wood via integrated gasification, synthesis, and methanol-to-gasoline technologies. Golden: National Renewable Energy Laboratory (NREL); 2011.

94. Ekbom T, Hjerpe C, Hagström M, Hermann F. Pilot study of bio-jet A-1 fuel production for Stockholm-Arlanda airport. Stockholm: VÄRMEFORSK Service AB; 2009

95. Kreutz TG, Larson ED, Liu G, Williams RH. Fischer-Tropsch fuels from coal and biomass. In: 25th annual international Pittsburgh coal conference. 2008

96. Farzad S, Rashidi A, Haghtalab A, Mandegari MA. Study of effective parameters in the Fischer Tropsch synthesis using monolithic CNT supported cobalt catalysts. Fuel. 2014;132:27-35.

97. Humbird D, Davis R, Tao L, Kinchin C, Hsu D, Aden A, Schoen P, Lukas J, Olthof B, Worley M. Process design and economics for biochemical conversion of lignocellulosic biomass to ethanol: dilute-acid pretreatment and enzymatic hydrolysis of corn stover. Golden: National Renewable Energy Laboratory (NREL); 2011.

98. Eisentraut A, Brown A, Fulton L. Technology roadmap: biofuels for transport. Parix Cedex: International Energy Agency; 2011.

99. Dutta A, Talmadge M, Hensley J, Worley M, Dudgeon D, Barton D, Groendijk P, Ferrari D, Stears B, Searcy EM. Process design and economics for conversion of lignocellulosic biomass to ethanol: thermochemical pathway by indirect gasification and mixed alcohol synthesis. Golden: National Renewable Energy Laboratory (NREL); 2011.

100. Aho M, Ferrer E. Importance of coal ash composition in protecting the boiler against chlorine deposition during combustion of chlorine-rich biomass. Fuel. 2005;84:201-12.

101. ISO I. 14044, Environmental management life cycle assessment requirements and guidelines. Managements environmental Analyse du cycle de vie. 2006.

102. Pallemaerts $M$. The new climate policies of the European Union: internal legislation and climate diplomacy. ASPNUBPRESS/UPA; 2010.

103. Guo M, Li C, Bell JNB, Murphy RJ. Influence of agro-ecosystem modeling approach on the greenhouse gas profiles of wheat-derived biopolymer products. Environ Sci Technol. 2012;46:320-30.

104. Guo M, Li C, Facciotto G, Bergante S, Bhatia R, Comolli R, Ferré C, Murphy R. Bioethanol from poplar clone Imola: an environmentally viable alternative to fossil fuel? Biotechnol Biofuels. 2015;8:1-21.

105. Mashoko L, Mbohwa C, Thomas VM. LCA of the South African sugar industry. J Environ Plan Manag. 2010;53:793-807.

106. Mashoko L, Mbohwa C, Thomas VM. Life cycle inventory of electricity cogeneration from bagasse in the South African sugar industry. J Clean Prod. 2013;39:42-9.

107. Ryding S-O. ISO 14042 Environmental management life cycle assessment life cycle impact assessment. Int I Life Cycle Assess. 1999;4:307.

108. Finnveden G, Hauschild MZ, Ekvall T, Guinee J, Heijungs R, Hellweg S, Koehler A, Pennington D, Suh S. Recent developments in life cycle assessment. J Environ Manag. 2009:91:1-21.

109. Berger M, van der Ent R, Eisner S, Bach V, Finkbeiner M. Water accounting and vulnerability evaluation (WAVE): considering atmospheric evaporation recycling and the risk of freshwater depletion in water footprinting. Environ Sci Technol. 2014;48:4521-8.

110. Guo M, Murphy R. LCA data quality: sensitivity and uncertainty analysis. Sci Total Environ. 2012:435:230-43.

111. Macrelli S, Mogensen J, Zacchi G. Techno-economic evaluation of 2nd generation bioethanol production from sugar cane bagasse and leaves integrated with the sugar-based ethanol process. Biotechnol Biofuels. 2012;5:22.

112. John RP, Nampoothiri KM, Pandey A. Fermentative production of lactic acid from biomass: an overview on process developments and future perspectives. Appl Microbiol Biotechnol. 2007;74:524-34.

113. Martín C, Klinke HB, Thomsen AB. Wet oxidation as a pretreatment method for enhancing the enzymatic convertibility of sugarcane bagasse. Enzym Microbial Technol. 2007;40:426-32.

114. Qureshi N, Saha BC, Hector RE, Hughes SR, Cotta MA. Butanol production from wheat straw by simultaneous saccharification and fermentation using Clostridium beijerinckii: part I — batch fermentation. Biomass Bioenergy. 2008;32:168-75.

115. Iglesias Gonzalez M, Kraushaar-Czarnetzki B, Schaub G. Process comparison of biomass-to-liquid (BtL) routes Fischer-Tropsch synthesis and methanol to gasoline. Biomass Convers Biorefin. 2011;1:229-43.

116. Bozzano G, Manenti F. Efficient methanol synthesis: perspectives, technologies and optimization strategies. Prog Energy Combust Sci. 2016;56:71-105.

117. Shamsul NS, Kamarudin SK, Rahman NA, Kofli NT. An overview on the production of bio-methanol as potential renewable energy. Renew Sustain Energy Rev. 2014:33:578-88.

118. Henrich E, Dahmen N, Dinjus E. Cost estimate for biosynfuel production via biosyncrude gasification. Biofuels Bioprod Biorefin. 2009;3:28-41.

119. Peplow M. Cellulosic ethanol fights for life. Nature. 2014;507:152-3.

120. Moka S, Pande M, Rani M, Gakhar R, Sharma M, Rani J, Bhaskarwar AN. Alternative fuels: an overview of current trends and scope for future. Renew Sustain Energy Rev. 2014;32:697-712.

121. Daystar J, Reeb C, Gonzalez R, Venditti R, Kelley SS. Environmental life cycle impacts of cellulosic ethanol in the Southern U.S. produced from loblolly pine, eucalyptus, unmanaged hardwoods, forest residues, and 
switchgrass using a thermochemical conversion pathway. Fuel Process Technol. 2015;138:164-74.

122. Pfromm PH, Amanor-Boadu V, Nelson R, Vadlani P, Madl R. Bio-butanol vs. bio-ethanol: a technical and economic assessment for corn and switchgrass fermented by yeast or Clostridium acetobutylicum. Biomass Bioenerg. 2010;34:515-24.

123. Alvira P, Tomas-Pejo E, Ballesteros M, Negro MJ. Pretreatment technologies for an efficient bioethanol production process based on enzymatic hydrolysis: a review. Bioresour Technol. 2010;101:4851-61.

124. Brown TR, Wright MM, Román-Leshkov Y, Brown RC. Techno-economic assessment (TEA) of advanced biochemical and thermochemical biorefineries. Adv Biorefin. 2014;2014:34-66.

125. Sikarwar VS, Zhao M, Clough P, Yao J, Zhong X, Memon MZ, Shah N, Anthony EJ, Fennell PS. An overview of advances in biomass gasification. Energy Environ Sci. 2016;9:2939-77.

126. Tao L, Aden A. The economics of current and future biofuels. In Vitro Cell Dev Biol Plant. 2009;45:199-217.

127. Foust TD, Aden A, Dutta A, Phillips S. An economic and environmental comparison of a biochemical and a thermochemical lignocellulosic ethanol conversion processes. Cellulose. 2009;16:547-65.

128. Balan V, Chiaramonti D, Kumar S. Review of US and EU initiatives toward development, demonstration, and commercialization of lignocellulosic biofuels. Biofuels Bioprod Biorefin. 2013;7:732-59.

129. Parajuli R, Dalgaard T, Jørgensen U, Adamsen APS, Knudsen MT, Birkved M, Gylling M, Schjørring JK. Biorefining in the prevailing energy and materials crisis: a review of sustainable pathways for biorefinery value chains and sustainability assessment methodologies. Renew Sustain Energy Rev. 2015;43:244-63.

130. Hess JR, Wright CT, Kenney KL. Cellulosic biomass feedstocks and logistics for ethanol production. Biofuels Bioprod Biorefin. 2007;1:181-90.

131. Kudakasseril Kurian J, Raveendran Nair G, Hussain A, Vijaya Raghavan GS. Feedstocks, logistics and pre-treatment processes for sustainable lignocellulosic biorefineries: a comprehensive review. Renew Sustain Energy Rev. 2013;25:205-19.
132. Vohra M, Manwar J, Manmode R, Padgilwar S, Patil S. Bioethanol production: feedstock and current technologies. J Environ Chem Eng. 2014;2:573-84.

133. Heidenreich S, Foscolo PU. New concepts in biomass gasification. Prog Energy Combust Sci. 2015;46:72-95.

134. Tilman D, Cassman KG, Matson PA, Naylor R, Polasky S. Agricultural sustainability and intensive production practices. Nature. 2002;418:671-7.

135. http://www.ecoinvent.org/database. Accessed 20 July 2016.

136. Cornelis G, Van Gerven T, Vandecasteele C. Antimony leaching from uncarbonated and carbonated MSWI bottom ash. J Hazard Mater. 2006;137:1284-92.

137. Mu D, Seager T, Rao PS, Zhao F. Comparative life cycle assessment of lignocellulosic ethanol production: biochemical versus thermochemical conversion. Environ Manag. 2010;46:565-78.

138. Renó MLG, Lora EES, Venturini OJ, Palacio JCE. Life cycle assessment of the methanol production from sugarcane bagasse considering two different alternatives of energy supply. In: 20th International congress of mechanical engineering, Gramado, RS, Brazil. 2009.

139. Consultants P. SimaPro analyst 6.0.4. Amersfoort: Consultants P; 2004.

140. Goedkoop M, Spriensma R. The eco-indicator99: a damage oriented method for life cycle impact assessment. Methodology report. 2001.

141. Hassuani SJ, Leal M, Macedo I: Biomass power generation. Sugar cane bagasse and trash Published by Programa das Nacoes Unidas para o Desenvolvimento and Centro de Technologi a Canavieriva, Peracicaba, Brazil; 2005 .

142. De Beer A, Boast M, Worlock B. The agricultural consequences of harvesting sugarcane containing various amounts of tops and trash. In: Proceedings of the South African Sugar Technologists Association. 1989; p. 107-10.

143. Moncada J, El-Halwagi MM, Cardona CA. Techno-economic analysis for a sugarcane biorefinery: Colombian case. Bioresour Technol. 2013;135:533-43.

\section{Submit your next manuscript to BioMed Central and we will help you at every step:}

- We accept pre-submission inquiries

- Our selector tool helps you to find the most relevant journal

- We provide round the clock customer support

- Convenient online submission

- Thorough peer review

- Inclusion in PubMed and all major indexing services

- Maximum visibility for your research

Submit your manuscript at www.biomedcentral.com/submit
() Biomed Central 